\title{
Bioactivity of phytochemicals in some lesser-known plants and their effects and potential applications in livestock and aquaculture production systems
}

\author{
H. P. S. Makkar ${ }^{\dagger}$, G. Francis and K. Becker \\ Institute for Animal Production in the Tropics and Subtropics (480b), University of Hohenheim, 70593 Stuttgart, Germany
}

(Received 23 October 2006; Accepted 16 February 2007)

\begin{abstract}
Livestock and aquaculture production is under political and social pressure, especially in the European Union (EU), to decrease pollution and environmental damage arising due to animal agriculture. The EU has banned the use of antibiotics and other chemicals, which have been shown to be effective in promoting growth and reducing environment pollutants because of the risk caused to humans by chemical residues in food and by antibiotic resistance being passed on to human pathogens. As a result of this, scientists have intensified efforts in exploiting plants, plant extracts or natural plant compounds as potential natural alternatives for enhancing the livestock productivity. This paper discusses work on the effects of various phytochemicals and plant secondary metabolites in ruminant and fish species. The focus is on (i) plants such as Ananas comosus (pine apple), Momordica charantia (bitter gourd) and Azadirachta indica (neem) containing anthelmintic compounds and for their use for controlling internal parasites; (ii) plants containing polyphenols and their applications for protecting proteins from degradation in the rumen, increasing efficiency of microbial protein synthesis in rumen and decreasing methane emission; for using as antioxidants, antibacterial and antihelmintic agents; and for changing meat colour and for increasing n-3 fatty acids and conjugated linoleic acid in meat; (iii) saponin-rich plants such as quillaja, yucca and Sapindus saponaria for increasing the efficiency of rumen fermentation, decreasing methane emission and enhancing growth; for producing desired nutritional attributes such as lowering of cholesterol in monogastric animals; for increasing growth of fish (common carp and Nile tilapia) and for changing male to female ratio in tilapia; and for use as molluscicidal agents; (iv) Moringa oleifera leaves as a source of plant growth factor(s), antioxidants, beta-carotene, vitamin C, and various glucosinolates and their degraded products for possible use as antibacterial, antioxidant, anticarcinogenic and antipest agents; (v) Jatropha curcas toxic variety with high levels of various phytochemicals such as trypsin inhibitor, lectin, phytate and phorbol esters in seeds limiting the use of seed meal in fish and livestock diets; and the use of phorbol esters as bio-pesticidal agent; and (vi) lesser-known legumes such as Entada phaseoloides seeds containing high levels of trypsin inhibitor and saponins, Sesbania aculeate seeds rich in non-starch polysaccharides and Mucuna pruriens var. utilis seeds rich in L-3,4-dihydroxyphenylalanine and their potential as fish feed; Cassia fistula seeds as a source of antioxidants; and the use of Canavalia ensiformis, C. gladiata and C. virosa seeds containing high levels of trypsin inhinitor, lectins and canavanine. The paper also presents some challenges and future areas of work in this field.
\end{abstract}

Keywords: aquaculture systems, bioactivity, livestock systems, phytochemicals, plant secondary metabolites

\section{Introduction}

Livestock and aquaculture production is under political and social pressure, especially in the European Union (EU), to decrease pollution and environmental damage arising from animal agriculture. Some antibiotics and growth promoters such as monensin, avoparcin, flavomycin, virginiamycin and

\footnotetext{
${ }^{\dagger}$ E-mail: makkar@uni-hohenheim.de
}

growth hormone have been shown to be effective in reducing environment pollutants, and in enhancing feed conversion efficiency and increasing the livestock productivity. However, since 2006, the EU has banned the use of antibiotics and other chemicals, because of the risk to humans of chemical residues in food and of antibiotic resistance being passed on to human pathogens. As a result of this, scientists have intensified efforts in exploiting plants, plant extracts or natural plant compounds as 
potential natural alternatives for enhancing livestock productivity. The use of various herbs and medicinal plants has a long history. They have been used since ancient times, especially in oriental countries, as remedial measures against various animal and human ailments. However, the intensification of livestock production and the advent of antibiotics led to a decline in their usage and less interest in providing scientific bases to their effects. The adverse effects of using antibiotics and other synthetic compounds on human and animal health and on product quality and safety have rejuvenated interest in the fields of 'phytochemistry, phytopharmacology, phytomedicine and phytotherapy' during the last decade. The plant kingdom might provide a useful source of new medicines, pharmaceutical entities and bioactive compounds for enhancing animal production and health; and food safety and quality, while conserving environment.

According to an estimate by the Food and Agriculture Organization (FAO), human consumption of fish is expected to touch 110 million metric tonnes (Mt) by 2010 from the current level of about $90 \mathrm{Mt}$. This, along with the 'livestock revolution' taking place, especially in developing countries, coupled with continued human population growth, urbanisation and income growth are imposing a huge burden on the environment and resources.

In this paper, we discuss work conducted largely in our laboratory over the last decade on the effects of various phytochemicals and plant secondary metabolites in ruminant and fish species. There are changing perceptions regarding the therapeutic potential of various plant secondary metabolites, which traditionally have been termed as antinutrients. It is hoped that the information collated and discussed here will lead to further exploration and use of plants, or natural plant products, to decrease environmental pollutants and enhance animal productivity. This sustainable and environmentally friendly approach to agriculture (clean, safe and green agriculture) would be a 'win-win' situation for both farmers and the society.

\section{Plants containing anthelmintic compounds}

Parasitism by gastrointestinal nematodes is one of the major constraints on livestock production, especially when the nutritional status of the animals is poor. Subclinical infections of gastrointestinal nematodes such as Ostertagia circumcinta, Trichostrongylus colubriformis and Haemonchus contortus decrease feed intake, body-weight gain, and milk and wool production. In subtropical and tropical areas of the world where the animals are on low quality feeds and have poor nutritional status, mortality and morbidity due to nematode infection are widespread (Singh et al., 2003). There is a growing realisation that chemical anthelmintic treatment, on its own, may not provide a longterm strategy for managing parasites in grazing animals. The widespread development and prevalence of resistant strains of nematode parasites and public concern over drug residues excreted in animal products have stimulated efforts to identify and use plant-based anthelmintic compounds.

Leaves of Ananas comosus (pineapple) and Momordica charantia (bitter gourd) have been assessed for their anthelmintic efficacy. These plants reduced faecal worm egg counts of infected calves (50 to $100 \mathrm{~kg}$ live weight) after weekly bolus doses for at least 2 weeks. Comparison of bolus doses $(1 \mathrm{~g}$ each of dry leaf plus molasses per $\mathrm{kg}$ body weight; weekly dose for 3 weeks) of $A$. comosus or M. charantia with albendazole (a single dose of $5 \mathrm{mg} / \mathrm{kg}$ body weight) showed similar levels of efficacy in reducing (94\%) faecal worm egg counts. Efficacy assessment of these plants for calves after inclusion in the urea molasses multinutrient blocks (35\% dry leaves in blocks; intake of block $250 \mathrm{~g} /$ day for 21 days) showed decreases of $80 \%$, and $77 \%$ in faecal worm egg counts by $A$. comosus- and M. charantia-containing blocks, respectively; and $89 \%$ reduction in faecal worm egg count was observed with fenbendazole-containing blocks $(0.5 \mathrm{~g}$ fenbendazole per $\mathrm{kg}$ block; intake of block $250 \mathrm{~g} /$ day for 7 days). Overall, the efficacy of $A$. cosmosus leaves was higher than that of M. charantia leaves (Daing and Win, 2006).

In studies conducted on calves in Bangladesh (Akbar and Ahmed, 2006), pineapple and neem (Azadirachta indica) leaves were also demonstrated to have anthelmintic effects. Fresh pine apple leaves $(1.6 \mathrm{~g} / \mathrm{kg}$ body weight) and fresh neem leaves ( $1 \mathrm{~g} / \mathrm{kg}$ body weight) (both leaves on a drymatter basis were $200 \mathrm{mg} / \mathrm{kg}$ body weight) given as a single dose were compared with that of albendazole given at a rate of $7.5 \mathrm{mg} / \mathrm{kg}$ body weight. On day 7 , the efficacy of albendazole $(100 \%$ reduction in faecal worm egg count) was higher than that of pineapple and neem leaves $(76 \%$ and $55 \%$ reduction, respectively; $P<0.01$ ); and on day 14 , the percent reduction in faecal worm egg counts for albendazole and pineapple ( $88 \%$ and $82 \%$ reduction) were higher than that for neem leaves (56\% reduction; $P<0.05$ ). Similar results were observed on day 21 (Akbar and Ahmed, 2006). In the same study, urea molasses multinutrient blocks were used as a vehicle for giving these plant materials to dairy cows kept in a research station. Freeze-dried leaves were incorporated in the blocks so that the intake of these leaves was $200 \mathrm{mg}$ dry matter per $\mathrm{kg}$ body weight of animals. The intake of the blocks was $500 \mathrm{~g} /$ day per cow $(40 \mathrm{mg}$ dry matter per $\mathrm{kg}$ body weight of animal per day) and the blocks were fed for a total of 5 days. After 15 days of consumption, blocks containing pineapple leaf decreased faecal worm egg counts by $72 \%$ and those containing neem leaves decreased by $45 \%$. In contrast, the control blocks (free of these leaves) reduced the count by only $5 \%$. These values after 60 days posttreatment were $84 \%, 63 \%$ and $18 \%$, respectively. Similar results were obtained when these blocks were tested in milking cows on-farm. Both the herbal remedies, when incorporated into the block, increased milk yield $(26 \%)$ and live weight of animals (15\%) significantly when compared with non-medicated blocks. The feeding of blocks 
containing pineapple and neem leaves increased farmers' net profits by $122 \%$ and $33 \%$, respectively (Akbar and Ahmed, 2006). These data on efficacy from all three treatments indicate that pineapple leaves are better herbal anthelmintics than neem leaves. Similarly, in Vietnam, feeding blocks containing pineapple leaves $(150 \mathrm{~g}$ dry leaves per kg block; intake of dry leaves: $1 \mathrm{~g} /$ day per animal) to growing heifers (average body weight: $177 \mathrm{~kg}$ ) decreased faecal worm egg counts by $74 \%$ to $86 \%$ after 90 days of feeding and increased the daily weight gain of beef heifers by approximately $26 \%$ when compared with those fed blocks without pineapple leaves (Doan et al., 2006).

The extent of use of these blocks, cost/benefit ratio and increase in income of farmers using these medicated blocks have been summarised in Makkar (2006). This paper also gives information on the use of some undefined herbal and commercial plant mixes for controlling nematodes and for enhancing productive and reproductive responses.

In contrast, the results from studies conducted in Africa on the effects of various plant sources, including pineapple leaves, on ruminant nematodes were less encouraging (Githiori et al., 2004). Although cysteine proteases (bromelain) present in pineapple plant are considered to have some anthelmintic properties, there is a need to identify the active principle in pineapple leaves unequivocally and to investigate its presence in various germplasm existing in Asia and Africa and in different countries within Asia. It is also evident from the studies reported from Asia that different amounts of pineapple leaves have been used by workers, giving almost similar efficacy against nematodes. The effect of environment and soil conditions could also affect the level of the active principle, and this also needs to be investigated.

Another plant that seems to have a direct effect on gastrointestinal nematodes is eucalyptus. It has been shown to be effective against $H$. contours and $T$. colubriformis (Bennet-Jenkins and Bryant, 1996; Lorimer et al., 1996). These effects are attributed to the presence of tannins/ polyphenols in eucalyptus.

In the past decade, many reports have emerged showing anthelmintic effects of tannins/polyphenols and the benefits they could provide to livestock by decreasing nematode load in extensive grazing production systems (Singh et al., 2003). These effects on nematodes are attributed to an improved protein supply due to increased rumen undegradable protein and their availability post-rumen and also to the direct action of tannins against nematodes. Recently in Tunisia, it was shown that Acacia cyanophylla foliage, a tannin-rich legume shrub species, has an antiparasitic effect in sheep. The faecal worm egg count in Barbarine lambs fed previously on oaten hay was reduced by $68 \%$ when they were fed acacia foliage for 25 days. Administration of polyethylene glycol (PEG; $50 \mathrm{~g} /$ day), a tannin-deactivating reagent, increased faecal worm egg counts slightly (34\%) in sheep on acacia compared with those on acacia without PEG. However, these treatments did not affect the composition and the structure of the parasite genera recovered after copro-culture (Akkari et al., 2007).

There is a need to develop a simple screening method to identify plants having anthelmintic potential. For tannin containing plants, it would be interesting to look into the correlation of chemical and biological tannin assays with anthelmintic bioassay(s) and with the reduction in nematode numbers observed in vivo.

\section{Plants containing tannins}

Tannins are polyphenolic substances. Their multiple phenolic hydroxyl groups lead to the formation of complexes primarily with proteins and to a lesser extent with metal ions, amino acids and polysaccharides. These are considered to have both adverse and beneficial effects depending on their concentration and nature as well as other factors such as animal species, physiological state of the animal and composition of the diet. Although research on tannins has a long history, considerable additional research must be carried out to exploit fully the benefits of incorporating tanninrich plants and agro-industrial by-products in livestock feed and to develop strategies to manage these resources effectively so that tannins do not produce adverse effects. Some of the beneficial effects of tannins are enhancement of rumen undegradable protein and making feed protein available post-ruminally for production purposes, enhancement of efficiency of microbial protein production, and protection of ruminants from bloat. Some tannins are also known to have strong anticarcinogenic and antioxidant activities (Perchellet et al., 1996; Riedl et al., 2002).

\section{Protection of protein from degradation in the rumen}

Feeding $100 \mathrm{~g}$ of air-dried A. cyanophylla leaves with $200 \mathrm{~g}$ of soya-bean meal increased daily gain of lambs by $55 \%$, when compared with lambs offered oaten hay-based diets. The increased daily gain was possibly a result of the soyabean proteins being protected from degradation in the rumen by the leaf tannins and the consequent increase in protein availability post-ruminally. To achieve such effects, soya-bean meal should be offered after consumption of the acacia leaves. In this experiment, diet total phenols (as tannic acid equivalent)/diet protein, and total tannins (as tannic acid equivalent)/diet protein ratios were 0.043 and 0.021 , respectively. Inclusion of higher amounts of acacia leaves to the concentrate had adverse effects on productivity (Ben Salem et al., 2005). Nsahlai et al. (1999) also demonstrated the potential to use tropical tanniniferous shrub/tree foliage to increase the proportion of rumen undegradable protein in sheep diets. They ascribed the increased growth rate in sheep fed on teff straw and supplemented with oilseed cakes with small amounts of Acacia albida pods, rich in condensed tannins, to increased organic matter and nitrogen intake and/or to a more efficient use of nutrients. Similarly, Bhatta et al. (2000) showed inclusion of $7.5 \%$ of tamarind (Tamarindus indica, Linn) seed husk in a 
concentrate diet $(0.75 \%$ tannin content in the diet) increased milk production and growth rate, which was attributed to the protection of dietary protein from degradation in the rumen. A simultaneous benefit obtained in these studies was the partitioning of excreted nitrogen in a manner that lower nitrogen was excreted in the urine and higher in the faeces, thus making available manure with a higher level of nitrogen for crop production. In the tropical countries, up to $70 \%$ of urine-nitrogen can be lost to the environment. Lowering the excretion of nitrogen in urine by using tannins could decrease environmental pollution in these regions significantly. The potential benefits of tannincontaining temperate forages, e.g. Lotus corniculatus, Lotus pedunculatus, and Hedysarum coronarium have been demonstrated in numerous studies in New Zealand (Barry and McNabb, 1999; Min et al., 2003).

Skatole and indole are flavour compounds formed in the rumen, which exert negative effects on meat flavour and quality. These compounds originate from deamination and decarboxylation of the amino acid tryptophan by rumen microbes and are present in meat fat. Rumen bacteria that produce a range of indolic compounds have recently been described (Attwood et al., 2006). In in vitro studies, condensed tannins from Lotus corniculatus have been demonstrated to reduce the production of skatole, and this was attributed to decreased rumen protein degradation by lotus tannins (Schreurs et al., 2004). Condensed tannins from Dorycnium rectum also inhibited skatole and indole formation in the in vitro rumen system (Tavendale et al., 2005). Conversely, Priolo et al. (2005) reported that when lambs were fed a good-quality grass (sulla, Hedysarum coronarium) containing tannins ( $\mathrm{CT}=1.8 \% \mathrm{DM})$, the supplementation of PEG did not affect the content of skatole in perirenal fat, suggesting that probably the low amount of tannins in the diet did not interfere with the biosynthesis of skatole. Further studies are needed to verify if tannins could play a role in decreasing fat skatole and indole in meat from animals allowed to graze (Vasta and Priolo, 2006).

\section{Increase in efficiency of microbial protein synthesis}

Microbial protein synthesis in vitro, expressed as ${ }^{15} \mathrm{~N}$ incorporation into microbes (or purine as an index of microbial protein) per unit of short-chain fatty acid (SCFA) production is higher in the presence of tannins. Although tannins decrease the availability of nutrients, they cause a shift in the partitioning of nutrients so that a higher proportion of available nutrients is channelled towards microbial mass synthesis than to SCFA production (Makkar, 2003). These results suggest that the in vivo beneficial effects of tannins, at low levels of intake, could also be due to higher efficiency of microbial protein synthesis in the rumen. The higher molar proportion of propionate in the in vitro fermentation system and lower protozoal counts produced by tannins (Makkar et al., 1995a and b) are consistent with the higher efficiency of microbial protein synthesis observed in the presence of tannins. Although in vivo effects of tannins on rumen protozoal counts and molar proportions of SCFAs are inconsistent (Waghorn et al., 1994; Wang et al., 1996), some evidence exists for lower protozoal number (Wang et al., 1994) and higher molar proportion of propionate (Waghorn et al., 1994) in presence of tannins. It has been shown that calliandra tannins at a level of $2 \%$ to $3 \%$ in the diet reduced fibre degrading bacteria but the efficiency of microbial protein synthesis was not affected. Similarly Leucaena leucocephala and leucaena hybrid KX2 tannins at levels of $7.3 \%$ and $11.6 \%$, respectively, in the diets did not affect microbial protein flow as estimated by excretion of urinary purine derivatives (McNeill et al., 1998 and 2000). The higher efficiency of digestion observed in systems containing low levels of tannins could be due to specific inhibition or enhancement of a group(s) of micro-organisms. The decrease in the rate of digestion of feeds by low levels of tannins (Makkar et al., 1995a) could also help synchronise the release of various nutrients, which in turn might be responsible for increased microbial efficiency.

Increasing the efficiency of microbial protein synthesis and decreasing the protein degradability of feed protein in the rumen are beneficial for ruminants, since they increase the supply of non-ammonia nitrogen to the lower intestine for production purposes. In addition, these effects lead to protein-sparing effects in ruminants and decreased methane emissions and nitrogen excretion to the environment, thereby reducing emission of environmental pollutants despite producing more meat, milk and wool. It is important to know the levels of tannins for such positive effects to be realised. The concentration of tannins should not be too high so that the true digestibility of the substrate is appreciably decreased. At these high concentrations of tannins, the advantage provided by the higher efficiency of microbial protein synthesis (higher proportion of truly degraded substrate leading to microbial mass synthesis) will be offset by the absolute lower amount of truly degraded substrate. Feeding strategies need to be designed to exploit the beneficial effects of tannins.

\section{Other beneficial effects of tannins}

Tannins isolated from leaves of various multipurpose trees and browses have anticarcinogenic activity (Perchellet et al., 1996). Proanthocyanidins (condensed tannins), both in free form and bound to proteins, have been shown to have free radical scavenging abilities (Hagerman et al., 1999) and decrease the susceptibility of healthy cells to toxic agents. Most polyphenols have strong antioxidant properties and inhibit lipid peroxidation and peroxygenases. Pistafolia $A$, a gallotannin, has strong free radical scavenging properties (Wei et al., 2002). A number of hydrolysable tannins including ellagitannins and 1-o-galloyl castalagin and casuarinin (present in Eugenia jambos) have been shown to have activity against cell carcinomas and tumour cell lines (Sakagami et al., 2000; Yang et al., 2000). Catechins, polyhydroxylated flavonoids, are present in a 
wide distribution of browses and tree leaves. These undergo considerable microbial and tissue biotransformations, which are present in blood. Efforts need to be directed on evaluating these novel compounds for enhancing animal health.

Tannins also protect ruminants from bloat and have anthelmintic effects (Kahn and Diaz-Hernandez, 2000). Legume tannins could also enhance the quality of silage by preventing excessive degradation of feed proteins. Tannins from browses are also effective against Clostridium perfringens and can be used to control C. perfringens mediated diarrhoea in pigs during the change of feed from liquid to solid feed (Makkar, 2003).

Hydrolysable tannins, 4,6-0-isoterchebuloyl-D-glucose and isoterchebulin present in terminalia macroptera bark have been shown to have antimicrobial activity against Pseudomonas fluorescens and Bacillus subtilis (Conrad et al., 2001). Another hydrolysable tannins, punicalagin present in some Ethiopian medicinal plants was active against Mycobacterium tuberculosis strains (Asres et al., 2001). Tannins from Vaccinium vitis-idaea could be used for treatment of periodontal diseases since they have antimicrobial activity against Porphyromonas gingivalis and Prevotella intermedia (Ho et al., 2001). Other plant extracts rich in tannins that have antibacterial effects are bearberry and cowberry, against Helicobactor pylori (Annuk et al., 1999) and Syzygium jambos, against Styaphyloccus aureus and Yersinia enterocolitica (Djipa et al., 2000).

Tannins have also been found to affect meat colour and quality. Feeding tannin-containing acacia or sulla leaves or carob pulp has been found to produce meat of lighter colour. The addition of PEG, a tannin-inactivating agent, reversed this effect, suggesting that the lighter colour produced is due to tannins (Priolo et al., 2002a, b and 2005). Decrease in blood haaemoglobin and myoglobin and iron utilisation by tannins (Garg et al., 1992; Bhatta et al., 2002) could contribute to the lightness of the meat (Priolo et al., 2000). The lighter meat produced as a result of feeding tannin could favour consumer preference in some regions. Fatty acid composition is associated with the risk or the prevention of several human illnesses. Herbages containing low amount of tannins increased $n-3$ fatty acid and conjugated linoleic acid (9-cis 11-trans C18:2; CLA) in lamb meat, compared with lambs fed concentrate (Priolo et al., 2005), enhancing meat nutritional properties for human consumption. However, Vasta et al. (2005) reported that feeding a diet containing tannins from carob pulp resulted in a lower content of CLA in meat, compared with lambs fed the same diet but supplemented with PEG. This change possibly results from the inhibition of ruminal microorganisms responsible for the biosynthesis of CLA during the biohydrogenation of linoleic acid.

\section{Toxicity by tannin-containing plants}

Oak poisoning from the consumption of oak leaves (Garg et al., 1992) and yellow-wood toxicity from the leaves of Terminalia, Clidemia and Ventilago have been attributed to the presence of hydrolysable tannins, in particular gallotannins (McSweeney et al., 2001 and 2003). Rumen microbes are capable of degrading hydrolysable tannins. The toxicity, therefore, appears to be due to absorption of degraded products of hydrolysable tannins and higher loads of phenols in the blood stream, which is beyond the capability of liver to detoxify them.

In fish, the presence of tannic acid, a hydrolysable tannin, at $2 \%$ of the diet of common carp (Cyprinus carpio L.) produced adverse effects after day 28 of feeding. The rejection of diet started on day 28 and a complete rejection was observed on day 40 . The average metabolic rate for the days 35 to 42 was significantly lower and the oxygen consumption of fish fed the diet containing tannic acid decreased. No such adverse effect was observed in common carp on inclusion of $2 \%$ quebracho tannin (a condensed tannin) in the diet. In carp, toxicity of tannic acid is higher than that of quebracho tannin. Protein sources of plant origin containing high amounts of tannins and in particular hydrolysable tannins should be used with caution as fish meal substitutes in carp diets (Becker and Makkar, 1999).

\section{Plants containing saponins}

Saponins are steroid or triterpene glycoside compounds found in a variety of plants. Here we present their biological effects on ruminants and fish. The saponin-rich plants having potential for exploitation in ruminant and fish production systems are also discussed.

\section{Effects on ruminants}

Effect on rumen fermentation. Various saponins affect gas and microbial mass production to different extents in in vitro gas systems containing buffered rumen microbes and feed. For example, acacia saponins decreased gas production, but increased microbial protein without affecting true digestibility. On the other hand, addition of quillaja saponins did not affect gas production, but increased microbial protein and truly degraded substrate. Since truly degraded substrate in an in vitro system can lead only to production of gas (fermentative gases plus the buffered gas produced through neutralisation of S(FA) and microbial mass, this implies that all of the increase in truly degraded substrate by quillaja saponins resulted in higher microbial mass, i.e. these saponins increased efficiency of microbial mass synthesis. The effects of yucca saponins differed from those of quillaja or acacia saponins. Yucca saponins decreased gas, increased microbial protein and increased true digestibility. These results suggested that the saponins affected partitioning of degraded nutrients such that higher microbial mass was produced at the cost of gas, and/or SCFA production (Makkar, 2005). Liu et al. (2003) showed an increase in microbial protein synthesis in the presence of tea saponins in an in vitro fermentation. However, Wang et al. (2000a) showed that microbial protein synthesis 
increased at a low level of yucca saponin $(15 \mu \mathrm{g} / \mathrm{ml})$ but decreased at higher concentrations $(75 \mu \mathrm{g} / \mathrm{ml})$. Other in vitro studies using the RUSITEC system did not show any significant effect of yucca saponin (100 mg sarsaponin/kg feed) (Śliwiński et al., 2002a and 2002b) or of sapindus saponins (Hess et al., 2003a) on microbial protein synthesis. At low concentrations, saponins from Panax ginseng and quillaja have been demonstrated to increase the growth of Escherichia coli (Sen et al., 1998a). Yucca saponins have also been shown to stimulate growth of Prevotella (Bacteroides) ruminicola present in the rumen (Wallace et al., 1994).

Abreu et al. (2004) and Hess et al. (2004) found an increase in duodenal flow of microbial-nitrogen in sheep fed Sapindus saponaria fruit. However, Hristov et al. (1999) did not obtain a significant effect of yucca saponin on microbial protein flow to the intestine in heifers. An increase of microbial nitrogen supply, efficiency of microbial-nitrogen supply, and faecal-nitrogen excretion with increasing levels of Sapindus rarak extract was observed, but this increase was not significant.

Effects of various saponins on ammonia levels and SCFA production have been recently reviewed (Wina et al., 2005a). Saponins have also been evaluated with a view to enhance protection of protein from degradation in the rumen and increase availability of protein post-ruminally. Inhibition of rumen proteolytic activity of yucca saponins has been demonstrated (Wallace et al., 1994). Saponins also form complexes with proteins and could decrease protein degradability (Sen et al., 1998b). Sapindus rarak saponins did not affect the protein degradation in in vitro rumen system (Muetzel et al., 2005). On the other hand, quillaja saponins decreased protein degradability of the concentrate, but not of hay-based diet (Makkar and Becker, 2000). These observations suggest that the nature of diet plays a considerable role in determining the effects of saponins. The addition of $S$. saponaria fruit to a sheep diet decreased plasma urea, suggesting that less ammonia was absorbed from the rumen (Abreu et al., 2004; Hess et al., 2004). This would decrease the energy lost in detoxification of ammonia by the liver and its discharge in urine as urea, contributing to the higher productivity. In addition, saponin addition would provide environmental benefits because less of the feed nitrogen would be discharged into the environment. In addition, quillaja and yucca saponins have also been shown to reduce methane emission (Pen et al., 2007).

The difference reported above on the effects of saponins on the levels and proportion of SCFA, ammonia level, proteolytic and protein degradability could be due to different types of saponins and/or different composition of diets. For field applications of saponins, the focus should be on characterisation of specific plant saponin-diet-biological effect interactions.

Saponins and rumen ecology. Studies on the effect of saponins and their products on methanogens (archaea) have attracted great attention lately because of the potential for improving the environment by decreasing the production of 'greenhouse gases'. However, these studies concentrated more on the measurement of methane emission than on the methanogens themselves. As some methanogens (10\% to $20 \%$ of total) live in association with protozoa (Newbold et al., 1997; Tokura et al., 1997), it was expected that reducing protozoa would also reduce methanogens, thus reducing methane production. The addition of yucca extract to a high roughage diet or to a mixed diet containing hay and barley grain did not reduce methane emission in a RUSITEC system (Śliwiński et al., 2002a and 2002b). However, reduced methane emissions in an in vitro system were obtained by adding sarsaponin, extracted from yucca to a starch diet and to a mixed diet (Lila et al., 2003). Pen et al. (2006) also reported a decrease in methane production by yucca extract when incubated with a roughage-based diet in an in vitro system. In this study, a decrease of protozoal number and increase in microbial population were observed with both yucca and quillaja extracts; however, the latter did not reduce methane production. Suppression of methane emission was also achieved by the supplementation of $S$. saponaria fruit (containing high levels of saponins) in the RUSITEC (Hess et al., 2003b). Saponins may kill or inactivate protozoa (Makkar et al., 1998b), resulting in a lower predation of bacteria by protozoa and a larger bacterial population, slowing protein turnover in the rumen. The slower protein turnover should lead to an increase in bacterial nitrogen flow to the duodenum and increase in productivity (Makkar and Becker, 2000; Wallace et al., 2002; Hess et al., 2004). As mentioned above, yucca, quillaja and acacia saponins enhanced both microbial mass production and efficiency of microbial protein synthesis, measured using both purine as a marker and ${ }^{15} \mathrm{~N}$ incorporation in rumen microbes (Makkar, 2005).

Methane emission was also suppressed when sheep were fed S. saponaria fruit (Hess et al., 2004). However, the suppression of methanogenesis was not associated with decreased methanogen counts, suggesting a suppression of activity per methanogen cell (Hess et al., 2004). Likewise, saponin in $S$. rarak extract did not reduce the archaeal or methanogen RNA concentration either in vitro or in vivo studies (Wina et al., 2005a). Dohme et al. (1999) also showed that methane suppression by defaunation is not accompanied by a reduction in methanogen counts. In most studies, methanogens have been measured using the anaerobic culture technique and cell counts of methanogens were measured as colony-forming units, or, methanogens have been measured using in situ hybridisation technique. These studies are limited to the effects of various oils and individual fatty acid supplementation (Dohme et al., 1999 and 2001; Hess et al., 2004). The methanogen cell count determination using culture-based techniques has the disadvantages of non-specificity and that not all microorganisms can be cultured (Makkar and McSweeney, 2005). In our studies, saponin-rich fractions from fenugreek seeds 
and Sesbania sesban leaves did not decrease methane emission in vitro, but methanogens and fungal population decreased and the population of fibre-degrading bacteria, Fibrobacter succinogens and Ruminococcus falvefaciens increased (Goel et al., 2007), when measured as fraction of total bacteria using quantitative real-time PCR technique (Denman and McSweeney, 2005). In this study protozoal population also decreased. There was no correlation between methanogens and protozoal population and methane production (Goel et al., 2007). Further studies are required to understand the relationship between microbial population and methane production.

Anaerobic fungi are important in the rumen for digesting fibre, but they only comprise a small proportion of the total mass of the rumen micro-flora. There is little information on the effect of saponins on ruminal fungi. In pure culture, Wang et al. (2000b) demonstrated that fungi, Neocallimastix frontalis and Pyromyces rhizinflata are highly sensitive to saponins from Yucca schidigera, and even at a low concentration of the saponin $(2.25 \mu \mathrm{g} / \mathrm{ml})$, the growth of both fungi was completely inhibited. However, Muetzel et al. (2003), using a membrane hybridisation technique showed that fungal concentration was not reduced when increasing levels of saponin containing Sesbania pachycarpa were included in an in vitro fermentation system. On the other hand, $S$. rarak extract reduced fungal RNA concentration in the rumen liquor in an in vitro rumen fermentation, but not in the rumen of sheep fed with $S$. rarak extract for 3 months (Wina, 2005). The fungal population was significantly higher when sheep were fed with 25 to 50 g/day of S. saponaria for 30 days (Díaz et al., 1993). It is possible that fungi adapt during long-term feeding.

There are very few in vitro studies on the effects of saponins on specific rumen bacteria. Using pure culture, Wallace et al. (1994) observed that the saponin fraction of $Y$. schidigera, when added at a concentration of $1 \%$ to the medium, stimulated the growth of Prevotella ruminicola, did not affect the growth of Selemonas ruminantium, suppressed the growth of Streptococcus bovis by prolonging the lag phase, and completely inhibited the growth of Butyrivibrio fibrisolvens. The same fraction at much lower concentrations ( 0 to $250 \mu \mathrm{g} / \mathrm{ml}$ ) in pure culture exhibited antibacterial activity towards non-cellulolytic bacteria, i.e. Streptococcus bovis, Prevotella bryantii B14 (formerly P. ruminicola) and Ruminobacter amylophilus, which is indicated by depressed growth after $14 \mathrm{~h}$ of the exposure (Wang et al., 2000b). Fibrobacter succinogens were unaffected but Ruminococcus albus and Ruminococcus flavefaciens were virtually unable to digest cellulose in the presence of yucca saponins. Wang et al. (2000b) concluded that yucca saponin had a more negative effect on grampositive bacteria than gram-negative bacteria. Muetzel et al. (2003) also found that $S$. pachycarpa did not affect $F$. succinogenes (Gram negative). The concentration of RNA from Fibrobacter sp. remained constant and was not affected by S. rarak extract either in vitro or in vivo (Wina et al., 2005b).
Using RUSITEC, the number of cellulolytic bacteria was reduced by $30 \%$ when $0.5 \mathrm{mg} / \mathrm{ml}$ yucca extract was added to alfalfa hay. It was also demonstrated that cellulolytic bacteria are more susceptible to yucca extract than amylolytic bacteria (Wang et al., 2000b). Another study where pure cultures were used showed that the growth of cellulolytic bacteria was slightly reduced by $S$. rarak extract (Ningrat et al., 2002).

In an in vivo study, Díaz et al. (1993) observed a significant increase in cellulolytic and total bacteria in the rumen of sheep fed with $S$. saponaria fruit. A similar observation was made by Thalib et al. (1996) who reported that total cellulolytic bacteria increased when sheep were fed with a methanol extract of $S$. rarak. However, a dramatic decrease in the RNA concentration of Ruminococci in short-term feeding of $S$. rarak extract and disappearance of this effect upon long term feeding indicated that there may be an adaptation of Ruminococcus sp. to $S$. rarak saponins (Wina, 2005). The mechanism of adaptation of bacteria to saponin still needs to be clarified. An increase in the thickness of the cell wall was observed in Prevotella bryanti grown in pure culture and adapted to yucca saponins (Wang et al., 2000b).

Microbial adaptation and persistency of effects. It has been observed that some plant products lose their effects on continuous ingestion of the plants by animals. Their effects are short-lived due to microbial adaptation. This calls for development of strategies (for example: ingestion on alternate day, ingestion for 3 to 4 days and followed by a break for 1 to 2 days) to beat the microbial adaptation. A negative effect of saponin-containing Sesbania sesban on protozoal counts or activity was evident in the in vitro studies but not in sheep fed $S$. sesban since the protozoal counts in the rumen increased markedly after several days of feeding (Newbold et al., 1997; Odenyo et al., 1997; Teferedegne et al., 1999; Teferedegne, 2000; Ivan et al., 2004). Based on these results, Newbold et al. (1997) suggested feeding saponins intermittently to prevent a quick increase in protozoal counts in the rumen. Thalib et al. (1996) showed that feeding saponin extract every 3rd day kept the protozoal counts low even after 3 weeks. On the other hand, S. rarak saponins did not lose their defaunating activity until 27 days when fed to sheep (Wina et al., 2005a). Evidence exists on the hydrolysis of saponins to sapogenin and epimerisation and hydrogenation of sapogenin in the rumen. The relative efficacy of original saponins and that of aglycon (sapogenin) and its epimerised and hydrogenated products towards various effects reported above is not known.

Machmüller et al. (2000) reported that the effects of coconut oil and oilseeds on methane suppression persisted for up to 7 weeks. It would be pertinent to study the persistency of the effects of plants. A challenge will be to develop approaches for using plants, plant extracts or plant products, which sustain their effects on the rumen microbial ecosystem. 
Other effects of saponin-containing plants. Fenugreek (Trigonella foenum-graecum L.) is a commonly cultivated plant in Asian and Middle Eastern countries. Several authors have estimated the levels of this steroidal sapogenin, both in the commercial varieties of fenugreek and during comparative studies on seeds from related plant species. Saponin levels (as diosgenin) of $0.07 \%$ to $1.64 \%$ have been observed in seeds (Taylor et al., 2002). In our laboratory, 3\% saponin (as diosgenin) (on a dry-matter basis) were recorded in fenugreek seeds (HPS Makkar, unpublished results). The seeds are known to reduce blood cholesterol and produce lower concentrations of cholesterol in milk and also to improve the profile of functional fatty acids (Shah and Mir, 2004). Cholesterol-reducing effects of fenugreek seeds (rich in saponins) have also been demonstrated in rats and humans (Petit et al., 1993; Al-Habori and Raman, 1998). Antiviral activity of saponins from Glycyrrhiza radix, immunostimulant activity of saponins from Quillaja saponaria Molina, and hypoglycaemic and antidiabetic activity of saponins from fenugreek (see Francis et al., 2002d) have also been demonstrated. Yucca, quillaja, S. rarak and Enterolobium cyclocarpum saponins have been shown to increase productive parameters such as wool production, growth and milk production in animals on roughage-based diets (Wina et al., 2005c). The effect of quillaja saponins was concentration and sex dependent. The growth rate was significantly higher for male lambs at 40 p.p.m. level, and at 60 p.p.m. the growth rate was higher than the control but the increase was not significant. On the other hand, inclusion of quillaja saponins at these levels decreased the growth rate of female lambs (Makkar, 2000). These effects seem to be mediated by hormones. Further studies are needed in this area. Supplementation of steroidal saponins in feeds has also been shown to be beneficial to fattening lambs and steers and monogastrics (see Makkar, 2000).

Saponins may be toxic to ruminants. The major symptoms are photosensitisation, gastroenteritis and diarrhoea. Some forages that contain saponins and produce these toxic symptoms are Brachiaria decumbens grass, species of the Panicum genus, and Drymaria arenaroides and Tribulus terrestris weeds (see Wina et al., 2005b). Toxicity of other saponin-containing plants such as Narthecium ossifragum, Tribulus terrestris, Agave lecheguilla and Nolina texana has also been described (Flaoyen et al., 2004).

In tropical countries, crop residues and poor quality hays and pastures form a major part of the animal diets. Ureaammoniation has been used extensively for enhancing the digestibility and in turn intake and nutrient utilisation from these low quality roughages. However, a major disadvantage of the ammoniation process is the loss of nitrogen in the form of ammonia that occurs during fermentation. Saponins are considered to bind ammonia. In one of our studies (Makkar et al., 1999), Quillaja saponaria bark saponins and Yucca schidigera plant extract rich in saponins were added during urea-ammoniation to reduce ammonia loss to the air. The ammonia-nitrogen bound to the straw (as percentage of urea-nitrogen added) varied from $47 \%$ to $54 \%$ in the presence of the yucca plant powder (1 g/kg straw), which was substantially higher than that observed in its absence (38\%). On the other hand, no such increase was observed with Quillaja saponaria bark saponins. The dry matter and NDF digestibilities, rate and potential extent of digestion were significantly higher in the treated straw than in the untreated straw; but these values were not affected by the addition of saponins and saponinrich yucca plant powder. The increase in binding observed in the presence of yucca plant powder could be due to the presence of saponins and/or glycoproteins.

\section{Effects on fish}

An overview of the effects of saponins on fish metabolism and performance is presented in Table 1.

Fish mortality and molluscicidal activity. Saponins have been reported to be highly toxic to fish because of their damaging effect on the respiratory epithelia (Roy et al., 1990). They are also considered to be the active components of many traditionally used fish poisons, like mahua oil cake (see Francis et al., 2001a). Fish have also been shown to exhibit stress reactions to the presence of saponins in water. Roy and Munshi (1989) reported that the oxygen uptake of perch, Anabas testudineus, increased with a concomitant increase in the red blood cells, haemoglobin and haematocrit levels, after the fish had been in water containing $5 \mathrm{mg} / \mathrm{l}$ quillaja saponin for $24 \mathrm{~h}$. Penaeus japonicus that had been previously exposed to concentrations of $20 \mathrm{mg} / \mathrm{l}$ of saponin for $24 \mathrm{~h}$ increased both respiration rate and metabolism (measured as increase in oxygen uptake and ammonia excretion) during a $6 \mathrm{~h}$ detoxification process (Chen and Chen, 1997). Bureau et al. (1998) observed that quillaja saponins damaged the intestinal mucosa in rainbow trout and Chinook salmon at dietary levels above $1500 \mathrm{mg} / \mathrm{kg}$. The condition of the intestines of these fish was similar to that of fish fed a raw soya-bean meal diet indicating the role of saponins in causing the damage. Krogdahl et al. (1995), however, did not find any negative effects when soya saponins were included in the diet of Atlantic salmon at levels similar to those likely to be found in a soya-bean meal-based diet (30 to $40 \%$ ). In the same study, an alcohol extract of soya-bean meal caused growth retardation, altered intestinal morphology and depressed mucosal enzyme activity in the lower intestine.

Our experiments showed that two commercially available saponin concentrates did not have any lethal effects on common carp. Addition of Quillaja saponaria saponins (QS: no. 2149; Sigma, St Louis, USA) at a level of 40000 p.p.m. in aquaria containing carp (Cyprinus carpio L.) did not lead to death of the carp in $18 \mathrm{~h}$ and feed consumption was not affected. On the other hand, yucca saponins (YS: DK sarsaponin $30^{\mathrm{TM}}$, Desert King International, Chula Vista, CA, USA) at 10000 p.p.m. did not cause mortality in the first $3 \mathrm{~h}$, but all fish were found dead after $18 \mathrm{~h}$. The foam formation, due to saponins, was observed in both aquaria; 
Effects and applications of phytochemicals

Table 1 Overview of the effects of saponins on common carp and Nile tilapia

\begin{tabular}{|c|c|}
\hline Parameter & Effect \\
\hline Toxicity & $\begin{array}{l}\text { No toxic effects in common carp and Nile tilapia when quillaja saponin extract present in feeds up to a level of } \\
2000 \text { p.p.m. No toxic effect in common carp when quillaja saponin extract present in water up to a level of } \\
40000 \text { p.p.m. }\end{array}$ \\
\hline Feed intake & $\begin{array}{l}\text { Feed intake not affected when the level of quillaja saponin extract in feed was up to } 2000 \text { p.p.m. for Nile tilapia } \\
\text { and } 250 \text { p.p.m. for common carp }\end{array}$ \\
\hline Growth & $\begin{array}{l}\text { Growth stimulated in common carp up to a level of } 150 \text { p.p.m. and } 300 \text { p.p.m. for Nile tilapia of quillaja saponin } \\
\text { extract }\end{array}$ \\
\hline Feed conversion efficiency & Feed conversion efficiency increased at the concentration at which growth was stimulated \\
\hline Enzyme activity & $\begin{array}{l}\text { Activities of lactate dehydrogenase (LDH) and cytochrome c-oxidase (CO) in liver of common carp increased on } \\
\text { feeding quillaja saponin containing diet. Intestinal enzymes amylase and trypsin was also stimulated }\end{array}$ \\
\hline $\begin{array}{l}\text { Oxygen consumption and } \\
\text { metabolic rate }\end{array}$ & $\begin{array}{l}\text { Oxygen consumption and metabolic rate not significantly affected by addition of saponin concentrates up to a } \\
\text { level of } 300 \text { p.p.m. in the diet. Absolute values tended to be lower for both the oxygen consumption and } \\
\text { metabolic rate }\end{array}$ \\
\hline Membrane transport & $\begin{array}{l}\text { Increase in paracellular transport of inert markers }\left({ }^{3} \mathrm{H} \text { mannitol) on application of quillaja saponins to the }\right. \\
\text { mucosal side of isolated tilapia intestinal membrane }\end{array}$ \\
\hline Reproduction & $\begin{array}{l}\text { Spawning affected in mature female Nile tilapia feeding on diet containing } 300 \text { p.p.m. of quillaja saponin } \\
\text { concentrate }\end{array}$ \\
\hline Sex determination & $\begin{array}{l}\text { Masculinisation of tilapia larvae feeding on a diet containing } 700 \text { p.p.m. of quillaja saponins. Suppression of } \\
\text { reproduction in Nile tilapia when first feeding larvae were fed diets containing } 2000 \text { p.p.m. of quillaja saponins }\end{array}$ \\
\hline Histology & $\begin{array}{l}\text { No abnormality observed in liver, kidney or intestinal tissue of tilapia fed quillaja saponins up to } 700 \text { p.p.m. in } \\
\text { the diet }\end{array}$ \\
\hline
\end{tabular}

however, there was no correlation between the extent of foam formation and toxicity of saponins to fish. Our results demonstrated that quillaja and yucca saponins are not highly toxic to fish (Makkar and Becker, 2000).

Molluscicidal activity of quillaja and yucca saponins was also very low compared with other saponins. At 20 p.p.m., yucca and quillaja saponins killed only $40 \%$ and $20 \%$ of the snails (Biomphalaria glabrata), respectively. At this level, $100 \%$ mortality was observed with acacia saponins (Makkar and Becker, 2000). Snails act as intermediate hosts of schistosomes in many tropical countries. Schistosomes cause schistosomiasis. Acacia auriculoformis saponins might hold potential for controlling this disease.

As mentioned above in context to rumen fermentation, protozoa are highly susceptible to some saponins. The use of saponin-containing plants for possible control of fish protozoal diseases such as white spot disease, costiasis and trichodiniasis needs investigation. Fish are also highly susceptible to some saponins. A challenge would be to identify saponins that affect the protozoa causing these diseases but do not adversely affect fish.

Feed intake and behaviour. We observed that common carp (Cyprinus carpio) and tilapia (Oreochromis niloticus) ate standard fish meal-based diets mixed with up to $1000 \mathrm{mg} /$ $\mathrm{kg}$ of all the saponin concentrates (QS and YS) that were evaluated without any hesitation. The fish consumed the pellets containing saponins as soon as they dropped into the aquaria with no apparent differences in acceptability between the control diet and saponin-containing diets.
There was no mortality or abnormal behaviour of fish fed up to this concentration of saponins. On the other hand, standard diets containing $2000 \mathrm{mg} / \mathrm{kg}$ of the quillaja saponin concentrate induced high mortality in first-feeding tilapia larvae (Steinbronn, 2002). Mortality started after 3 weeks of intensive feeding of the diet containing $2000 \mathrm{mg} / \mathrm{kg}$ of QS and 93 out of 460 fish larvae died over a period of about 5 days. The mortality stopped completely after the feeding intensity was reduced and the saponin-containing diet was gradually replaced with a standard diet (the control diet was a standard diet containing, on dry-matter basis, $40 \%$ protein, $10 \%$ lipid, $10 \%$ ash and had $20 \mathrm{~kJ} / \mathrm{g}$ gross energy with the protein source being fish meal).

Effects of low levels of quillaja saponins on fish growth. Common carp and Nile tilapia juveniles fed diets containing QS (150 and $300 \mathrm{mg} / \mathrm{kg}$ in the diet) had significantly higher rate of body mass gain (Francis et al., 2001b and 2002a). The average final body mass of carp fed QS was about $18 \%$ higher and that of tilapia was more than $20 \%$ higher than fish that had similar average weights at the start of the respective experiments but which did not receive QS (Figures 1 and 2).

The growth-promoting effects of QS were most pronounced at $150 \mathrm{mg} / \mathrm{kg}$ diet for carp; whereas, the dietary level of $300 \mathrm{mg} / \mathrm{kg}$ induced maximum effects in tilapia. The absolute increase in weight was higher compared with control animals even at higher dietary levels of $700 \mathrm{mg} / \mathrm{kg}$ in Nile tilapia (Francis et al., 2002c). The growth-promoting effects of QS were most pronounced during the initial 


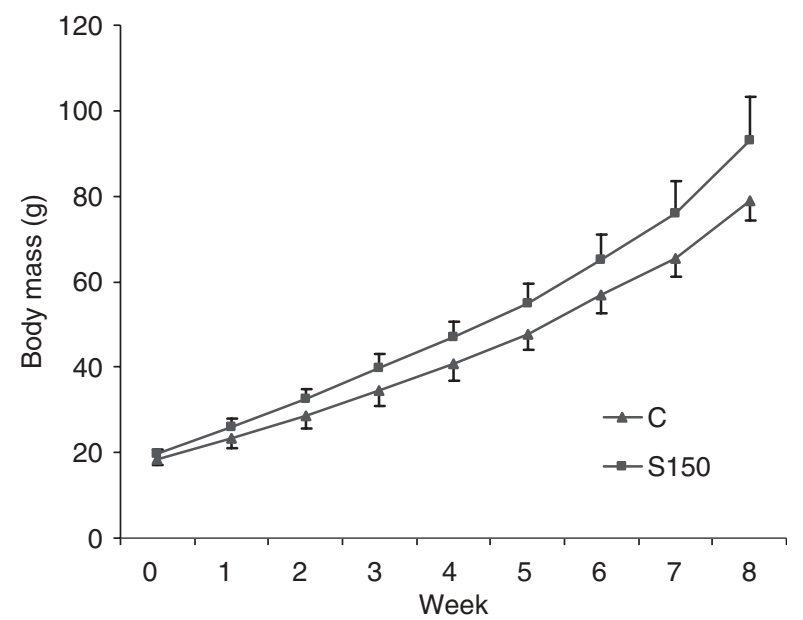

Figure 1 Body mass increase of common carp fed control diet (C) or a diet containing $150 \mathrm{mg} / \mathrm{kg}$ (S150) of quillaja saponins (taken from Francis et al., 2002a).

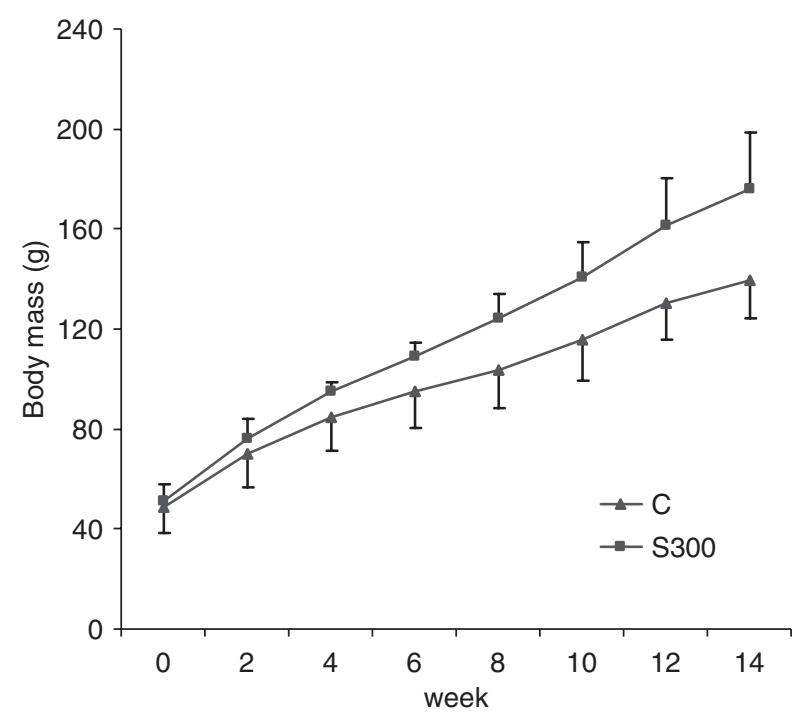

Figure 2 Body mass increase of Nile tilapia fed control diet (C) or a diet containing $300 \mathrm{mg} / \mathrm{kg}$ (S300) of quillaja saponins (taken from Francis et al., 2001b).

period of feeding (Francis et al., 2001b and 2002a). It was therefore hypothesised that there was probably an adaptation by the fish to continuous intake of QS. An experiment was therefore designed to provide discontinuous ingestion of saponins to counteract any adaptive responses of the fish (Francis et al., 2002b). Consumption of diets containing saponins during alternate weeks, however, did not result in retention of the more pronounced initial growth-promoting effects during the entire experimental period in carp. Haemolytic triterpenoid gypsophila saponins (GSs) at levels of between 5 and $250 \mathrm{mg} / \mathrm{kg}$ in diets (GS5 and GS250), concentrated using chromatography, did not increase growth rates of common carp after 8 weeks of feeding even though absolute growth was higher in all the saponin-fed groups compared with control (G. Francis, H.P.S. Makkar and K. Becker, unpublished data).

Concentrated steroidal YS at levels of 50 and $100 \mathrm{mg} / \mathrm{kg}$ (YS050 and YS100 groups) also did not affect growth of common carp significantly. Here the YS050 group seemed to perform better than the YS100 and control groups at the end of a 10-week feeding experiment (G. Francis, H.P.S. Makkar and $\mathrm{K}$ Becker, unpublished data). The metabolic growth rate ( $M G R=$ live weight gain (g)/average metabolic live weight $\left(\mathrm{kg}^{0.8}\right)$ per day) of the YS100 group was higher than that of the control group until the 7th week of the experiment, the difference between the two groups widened with time. Thereafter, the MGR of the control group started to increase compared with the YS100 and continued to do so until the end of the experiment. The YS050 group had the lowest growth rate throughout the experiment.

The addition of QS to the diet reduced the amount of feed required for the synthesis of tissue protein. The food conversion ratio (FCR) was lower in carp fed a diet containing $150 \mathrm{mg} / \mathrm{kg}(0.82 \pm 0.07)$ and tilapia fed $300 \mathrm{mg} /$ $\mathrm{kg}(1.40 \pm 0.19)$ of QS compared with the controls $(0.89 \pm 0.04$ and $1.61 \pm 0.34)$. Common carp fed diets containing GS and YS did not differ from controls in regard to FCR (G. Francis, H.P.S. Makkar and K. Becker, unpublished observation) with values of 0.91 for control, 0.96 for YS050 and 0.91 for YS100. In the case of the GS, the absolute FCR value was lowest in the GS5 group and highest in the control group (G. Francis, H.P.S. Makkar and K. Becker, unpublished observations).

Differences in growth rate and feed efficiency of fish fed saponin-containing diets were not always significantly higher compared with controls because of the high variability among treatment groups. The lack of homogeneity in the growth-promoting effects of dietary QS was also evident during feeding experiments where the number of experimental fish was relatively high, both in the laboratory (Francis et al., 2002c) and field trials (Steinbronn, 2002). The variability was evident despite the fact that fish used in the individual experiments were of the same lineage, age and body mass. The factors that may have caused variability in the growth response of carp and tilapia to dietary QS are not clear.

The mechanisms contributing to growth-promoting effects of saponins, especially QS which induced significant growth increases, remain unclear. Diverse effects of dietary saponins include an increase in the permeability of intestinal membranes to dietary nutrients (Francis et al., 2002d) and/or a stimulation of the activity of digestive enzymes, which increases the efficiency of feed nutrient utilisation. Dietary QS increased significantly the activity of intestinal enzymes, amylase and trypsin, suggesting stimulation of protein and carbohydrate digestion in the intestine. Increase in liver enzymes, lactate dehydrogenase (LDH) and cytochrome c-oxidase (CO) was also observed on feeding QS containing diet (Serrano et al., 1998). This suggests that QS promoted the respiratory chain pathway, enhancing energy 
availability. The ratios of LDH to CO decreased with QS supplementation (Serrano et al., 1998) indicating the promotion of aerobic metabolism.

Initial investigations into the effects of saponins on membrane transport reveal an increase in paracellular transport of inert markers $\left({ }^{3} \mathrm{H}\right.$ mannitol) on application of QS to the mucosal side of isolated tilapia intestinal membrane (G. Francis, H.P.S. Makkar and K. Becker, unpublished observations).

It also remains to be determined whether the saponins themselves or their breakdown products (e.g. sapogenins) in the intestines enter the blood of the fish and cause their effects systemically. From the extent of effects that saponins have on various physiological processes it is expected that either saponins or their breakdown products enter the body through the intestinal membranes. We have described the ability of saponins to influence serum hormone levels (Francis et al., 2002d). However, some dietary components may produce systemic effects even without actually entering the body. It has been reported that hormones such as ghrelin synthesised primarily in the stomach wall could act as intermediaries between stomach, hypothalamus and pituitary and may be involved in energy balance (Tschöp et al., 2000). It is to be seen whether saponins induce the synthesis and release of such hormonal intermediaries in the digestive system.

A factor that makes it more difficult to interpret the effect of dietary saponins is the presence of a number of individual compounds with different properties in the saponin mixtures used in our feeding trials. We conducted some experiments to see if there are functional differences between purified haemolytic saponin fractions and crude extracts for their growth-promoting effects. Our initial studies indicate that there are no differences in growth or any of the nutrient assimilation parameters between carp fed raw GS mixture or any of the levels of haemolytic saponins ( 5 to $250 \mathrm{mg} / \mathrm{kg}$ of the diet). The growth performance of all the saponin-fed groups was higher than that of the control fish in this experiment (G. Francis, H.P.S. Makkar and K. Becker, unpublished observations). Further studies might clarify whether individual compounds possess higher potency as growth enhancers in fish.

Even though there appears to be a stimulatory effect of saponins, particularly QS, on fish growth, gaps exist in our understanding of the mechanism of action of the saponins in fish. Future research in this area should concentrate on understanding the physiological mechanisms by which dietary saponins increase growth and feed conversion efficiency in carp and tilapia.

Effects on fish histology. It has been observed that QS does not cause any obvious damage to the intestinal membranes in tilapia fry when present up to $700 \mathrm{mg} / \mathrm{kg}$ in the diet. Neither was any abnormality observed in the liver or kidney tissue of tilapia fed QS up to $700 \mathrm{mg} / \mathrm{kg}$ over a period of 6 months (G. Francis and K. Becker, unpublished observations).
Effects on tilapia reproduction. Sexually mature female tilapia consuming a diet containing $300 \mathrm{mg} / \mathrm{kg}$ of QS did not spawn over a period of more than 3 months, whereas fish fed the control diet and reared under similar conditions spawned regularly. This observation was followed up by conducting laboratory experiments and field studies to explore further the effects of dietary QS on tilapia reproduction. Adult tilapia that were spawning regularly stopped egg laying when put on a diet containing $300 \mathrm{mg} / \mathrm{kg}$ of QS (G. Francis and K. Becker, unpublished observations). In another experiment, the sex ratio of tilapia larvae fed a diet containing $700 \mathrm{mg} / \mathrm{kg}$ of QS continuously over a 6-month experimental period deviated significantly from the normal $50 / 50$ ratio in favour of males (Francis et al., 2002c). This deviation from the normal sex ratio in favour of males was also evident (but not statistically significant) in the treatment groups receiving lower quantities of QS $(150 \mathrm{mg} / \mathrm{kg}$ diet) in the diet. Pond experiments conducted with a higher number of fish (about 500 larvae in each treatment in duplicate) fed a QS-containing diet for the first 6 weeks of life, however, did not confirm the laboratory results obtained regarding the effects of dietary QS on sex ratio (Steinbronn, 2002). The sex ratios of tilapia larvae fed diets containing 150 and $500 \mathrm{mg} / \mathrm{kg}$ of QS did not differ significantly from 50/50 ratio for males and females, but the share of males was slightly higher in both treatments when compared with the control group. In contrast, at the highest level of $2000 \mathrm{mg} / \mathrm{kg}$ diet, more females than males were counted in tilapia larvae fed these diets. This treatment group experienced $20 \%$ mortality during the early rearing phase when the saponin containing diets were being fed. It remains to be confirmed whether this might have been caused by differential mortality rates among the sexes during the experimental period. Pandian and Sheela (1995) have reported the likelihood of sex-dependent mortality occurring among fish that were sex-reversed through the application of synthetic hormones. The GIFT tilapia (developed from the 'Genetic Improvement of Farmed Tilapia' project of ICLARM (International Centre for Living Aquatic Resources Management), currently World Fish Centre) larvae used in the field trial have also been reported to generally have a higher number of female fish (Hussain et al., 2000). Continued observations revealed that production of fry was completely suppressed in ponds where fish from the $2000 \mathrm{mg} / \mathrm{kg}$ saponin group were stocked even after the removal of saponins from the diets (Steinbronn, 2002). This could point to a sterility of either males or females, which implies a potential for control of reproduction in tilapia using QS. Normal fry production was observed in fish that previously received 150 and $500 \mathrm{mg} / \mathrm{kg}$ of QS.

Saponins have been reported to affect the release of hormones, such as LH from the pituitary (Benie et al., 1990); this hormone is considered to regulate all aspects of teleost reproduction (Suzuki et al., 1988a), particularly final oocyte maturation and ovulation (Suzuki et al., 1988b). Therefore, it was hypothesised that induction of changes in $\mathrm{LH}$ secretory pattern by QS or its degraded products absorbed 
from the intestine might be responsible for the effects that have been observed on reproduction. QS was found to stimulate LH release from dispersed tilapia pituitary cells in vitro (Francis et al., 2002d). This effect was abolished in the presence of dilute calf serum. Serum LH values did not show any diet-dependent (QS containing or control diets) trend in either male or female tilapia in vivo. The retarding effects on egg production in adult females and the capacity for sex inversion in tilapia fry fed saponin-containing diets indicate effects at the hormonal level and data from gonadosomatic index measurements support this contention. Our efforts to identify any saponin-induced change in the level of LH did not reveal any dose-dependent patterns. Once the optimum dietary level of saponins that produces complete sex inversion in tilapia fry or prevents egg production in female tilapia is determined, saponins will have considerable potential in tilapia aquaculture where one of the major problems is overproduction of fry that do not grow to marketable size. The effect of saponins on levels of reproductive hormones should be studied further by monitoring hormones such as oestrogen, testosterone, 11-keto-testosterone and gonadotropic hormones in vivo and possibly by using cultured tilapia pituitary cells. In vitro studies have the advantage of requiring only small quantities of material for the identification of the individual compounds responsible.

\section{Plants containing multibioactive compounds}

\section{Moringa oleifera}

M. oleifera Lam (synonym: Moringa pterygosperma Gaertner) belongs to a monogeneric family of shrubs and trees, Moringaceae is considered to have its origin in the northwest region of India, south of the Himalayan mountains. This tree can be found growing naturally at elevations of up to $1000 \mathrm{~m}$ above sea level. It can grow well on hillsides but is more frequently found growing on pastureland or in river basins. It is a fast growing tree and has been found to grow 6 to $7 \mathrm{~m}$ in 1 year in areas receiving less than $400 \mathrm{~mm}$ mean annual rainfall. Various bioactive compounds present in different parts of this plant are presented in Table 2.

Moringa seeds contain between $30 \%$ and $42 \%$ oil, which is edible and the press cake obtained as a by-product of the oil extraction process contains a very high level of protein. Some of these proteins (approx. 1\%) are active cationic polyelectrolytes having molecular weights between 7 and $17 \mathrm{kDa}$. The cationic polyelectrolytes neutralise the colloids in muddy or dirty water since the majority of these colloids have a negative electrical charge. This protein can therefore be used as a non-toxic natural polypeptide for sedimenting mineral particles and organics in the purification of drinking water, for cleaning vegetable oil, or for sedimenting fibres in the juice and beer industries. It works as a primary coagulant as natural bridges are continuously formed between the colloid particles. These proteins have antibacterial properties and bind strongly with rumen microbes. At high levels these proteins inhibit rumen fermentation, but at low levels they protect feed proteins from degradation in the rumen (Makkar and Becker, 1998; Hoffmann et al., 2003) and could be used to enhance rumen undegradable protein. In vivo studies in this area are underway in Tunisia. The bacterial resistance to antibiotics is increasing in various regions and this obviously has huge implications in curing infectious diseases and in using antibiotics in feeds as growth promoters. The moringa protein also has bactericidal activity (Suarez et al., 2005). Gram-positive and Gram-negative bacteria, pathogenic to humans, showed only a slight reduction of viability with the moringa protein (Suarez et al., 2005), while viability of E. coli was inhibited by four orders of magnitude (Suarez et al., 2003). The use of antibacterial moringa proteins for controlling mastitis is also being investigated by us.

Some of the compounds that have been isolated from moringa seeds are 4-( $\alpha$-L-rhamnopyranosyloxy) benzyl glucosinolate (3\%), 4-(4'-0-acetyl- $\alpha$-L-rhamnopyranosyloxy) benzyl isothiocyanate, 4-( $\alpha$-L-rhamnopyranosyloxy) benzyl isothiocyanate $(10 \%)$, niazimicin, and pterygospermin (Daxenbichler, 1991; Fahey et al., 2001; Bennett et al., 2003; Mekonnen and Dräger, 2003). These compounds are known to have anticancer, antibacterial and hypotensive activities. Antioxidant activity of these compounds has also been reported (Win and Jongen, 1996). These compounds also have the potential to control agricultural and public health insect pests (Tsao et al., 1996). For example, Helicobacter pylori bacterium was found to be highly susceptible to 4-( $\alpha$-L-rhamnopyranosyloxy) benzyl isothiocyanate and various other isothiocyanates, which are degraded products of glucosinolates (Fahey et al., 2002; Haristoy et al., 2005). H. pylori is a major cause of gastric and duodenal ulcers, and is a major risk factor for gastric cancer.

Seed powder of moringa has been shown to protect animals from arsenic-induced oxidative stress and in the depletion of arsenic from blood, liver and kidneys (Gupta et al., 2005).

Extracts of moringa leaves in $80 \%$ ethanol contain growth enhancing principles (i.e. hormones of the cytokinine type). The extract as a foliar spray can be used to accelerate the growth of young plants such as peanut, soya bean, blackbean, maize, onion, sorghum, tomato, coffee and sugarcane (Foidl et al., 2001). Use of this spray also makes the plants firmer and more resistant to pests and disease, produce more and larger fruit and, consequently, have higher yields.

Moringa leaves are free of antinutritive factors (e.g. tannins, saponins, cyanogens, glucosinolates, alkaloids, etc.) and are high in iron (up to $582 \mathrm{mg} / \mathrm{kg} \mathrm{DM}$ ), betacarotene (up to $400 \mathrm{mg} / \mathrm{kg} \mathrm{DM}$ ) and in vitamin C (up to $9.2 \mathrm{~g} / \mathrm{kg} \mathrm{DM}$ ). Lately, this plant has received a lot of attention. All essential amino acids are at higher than adequate concentrations when compared with the recommended amino acid pattern of the FAO/WHO/UNO reference protein for 2- to 5-year-old children. Moringa foliage has been found to increase animal productivity (Foidl et al., 2001; Sánchez et al., 2006). 
Table 2 Phytochemicals in Moringa oleifera and their bioactivity

\begin{tabular}{|c|c|c|c|c|}
\hline Phytochemical & $\begin{array}{l}\text { Plant } \\
\text { part }\end{array}$ & Activity & Remark & Reference \\
\hline \multirow[t]{2}{*}{ Cationic protein } & & $\begin{array}{l}\text { Increase rumen by-pass protein } \\
\text { (in vitro, in a rumen } \\
\text { fermentation system) }\end{array}$ & $\begin{array}{l}\text { Possible use for enhancing feed } \\
\text { protein supply postruminally }\end{array}$ & $\begin{array}{l}\text { Makkar and Becker, } \\
\text { 1998; Hoffmann } \\
\text { et al., } 2003\end{array}$ \\
\hline & & Antibacterial & $\begin{array}{l}\text { Potential for controlling of various } \\
\text { diseases }\end{array}$ & $\begin{array}{l}\text { Suarez et al., } 2003 \\
\text { and } 2005\end{array}$ \\
\hline $\begin{array}{l}\text { 4-( } \alpha \text {-L-Rhamnopyranosyloxy) benzyl } \\
\text { glucosinolate (3\%); 4-(4'-0-acetyl- } \alpha \text { - } \\
\text { L-rhamnopyranosyloxy) benzyl } \\
\text { isothiocyanate; } 4 \text { - }(\alpha- \\
\text { L-rhamnopyranosyloxy) benzyl } \\
\text { isothiocyanate }(10 \%) \text {, niazimicin and } \\
\text { pterygospermin }\end{array}$ & Seed & $\begin{array}{l}\text { Anticancer, hypotensive and } \\
\text { antioxidant; antibacterial and } \\
\text { insecticidal }\end{array}$ & $\begin{array}{l}\text { Potential for use as } \\
\text { neutraceuticals; potential for } \\
\text { controlling bacterial diseases and } \\
\text { for pest management }\end{array}$ & \\
\hline Flavonoids: quercetin and kaempferol & Leaves & Antioxidant & $\begin{array}{l}\text { Leaves used to enhance shelf life } \\
\text { of 'Ghee' in India }\end{array}$ & $\begin{array}{l}\text { Siddhuraju and } \\
\text { Becker, } 2003\end{array}$ \\
\hline Beta-carotene & Leaves & Vitamin A precursor & $0.04 \%$ in dry matter & Foidl et al., 2001 \\
\hline Vitamin C & Leaves & A vitamin and an antioxidant & ca $1 \%$ in dry matter & Foidl et al., 2001 \\
\hline Cytokinine-type hormones & Leaves & $\begin{array}{l}\text { Enhance plant growth, yield } \\
\text { and pest resistance }\end{array}$ & $\begin{array}{l}\text { Active component in } 80 \% \\
\text { methanol; this solution is sprayed } \\
\text { on the plant }\end{array}$ & Foidl et al., 2001 \\
\hline Fibre & Leaves & $\begin{array}{l}\text { Decrease cholesterol in muscle } \\
\text { (fish) }\end{array}$ & Potential health benefits & $\begin{array}{l}\text { N. Mushota, } \\
\text { P. Siddhuraju, } \\
\text { K. Becker, } \\
\text { unpublished data }\end{array}$ \\
\hline Active compound & Leaves & $\begin{array}{l}\text { Decrease cholesterol in muscle, } \\
\text { liver, serum (rats) }\end{array}$ & $\begin{array}{l}\text { Decreased the high-fat diet- } \\
\text { induced increases cholesterol } \\
\text { levels. The effect could be due to } \\
\text { fibre in leaves }\end{array}$ & Ghasi et al., 2000 \\
\hline Active compound & Leaves & Increase breast milk production & $\begin{array}{l}\text { Used in Philippines by lactating } \\
\text { mothers }\end{array}$ & Foidl et al., 2001 \\
\hline $\begin{array}{l}\text { Flavonoids: quercetin, kaempferol, } \\
\text { rhamnetin, isoquercitrin and } \\
\text { kaempferitrin }\end{array}$ & Flowers & $\begin{array}{l}\text { Stimulant, aphrodisiac, diuretic } \\
\text { and cholagogue in humans }\end{array}$ & Used in Asian countries & Pal et al., 1995 \\
\hline
\end{tabular}

Pal et al. (1995) have reported that the methanol fraction of moringa leaf extract possesses antiulcer activity against gastric lesions induced in rats. Flowers of moringa are considered to possess medicinal value as a stimulant, aphrodisiac, diuretic and cholagogue, and they have been also reported to contain flavonoid pigments such as quercetin, kaempferol, rhamnetin, isoquercitrin and kaempferitrin (Nair and Subramanian, 1962). The administration of extracts of moringa leaves along with high-fat diet to rats decreased the high-fat diet-induced increases in serum, liver and muscle cholesterol levels by approximately 14\%, $6 \%$ and $11 \%$, respectively (Ghasi et al., 2000). Moringa leaves have also been shown to increase breast milk production (Estrella et al., 2000). In many Asian and African countries women consume moringa leaves to enhance breast milk production (Fuglie, 2001). In India, tribal and indigenous people use fresh leaves as a natural antioxidant in buffalo and cow ghee (butter oil) preparation, which is considered to enhance shelf life of ghee. Moringa leaves have very strong antioxidant activity (Siddhuraju and Becker, 2003;
Yang et al., 2006). The flavonoids such as quercetin and kaempferol were identified as the most potent antioxidants in moringa leaves. Their antioxidant activity was higher than the conventional antioxidants such as ascorbic acid, which is also present in large amounts in moringa leaves (Siddhuraju and Becker, 2003). The extracts of these leaves also appear to have cancer preventive effect, which was assayed by the differentiating activity against human promyelocytic leukaemia cells (HL-60) (Siddhuraju and Becker, 2003).

Moringa seeds contain phytate, cyanogens and glucosinolates (Makkar and Becker, 1997c). The pods of M. oleifera contain a glycoside niazine possessing an o-nitrile thiocarbamate group along with thiocarbonate, carbamate and isothiocyanate glycosides, which are considered to have hypotensive effects (Faizi et al., 1997).

By combining the knowledge of indigenous people with the laboratory findings that the moringa leaves have strong antioxidant activity and they are good sources of essential amino acids, these leaves could serve as a food source and 
their extracts containing flavanoids and other phytochemicals (not yet identified; for example for inducing milk production) may have potential as 'neutraceuticals' for improving the health of human and livestock.

\section{Jatropha curcas}

J. curcas (L.) or physic nut is a multipurpose and droughtresistant large shrub or small tree. Although a native of tropical America, it now thrives throughout Africa and Asia. It grows in a number of climatic zones in tropical and subtropical regions of the world and can be grown in areas of low rainfall. Jatropha is easy to establish, grows relatively quickly and is hardy. A perceived advantage of jatropha is its capability to grow on marginal land and its ability to reclaim and restore eroded areas. Various parts/ products of the plant hold potential for use as bio-fuel, animal feed and inclusion in medicinal preparations. If grown on barren lands it could add to the removal of carbon from the atmosphere and the build up of soil carbon.

Seed production ranges from about $0.1 \mathrm{t} / \mathrm{ha}$ per year to over $8-$ t/ha per year (Heller, 1996). The seed yield reaches peak levels after about 5 years of growth. This range in production may be attributable to low and high rainfall areas and the nutrients in soil. The plant takes about 4 to 5 years to yield seeds when cultivated on poor soil, with no irrigation and placed on locations in full sunlight, but much less time is required under optimal rainfall and soil conditions. Once established the plantations yield for 30 to 35 years.

Jatropha plants have been mainly investigated as a source of oil. The seed kernel of the plant contains about $60 \%$ oil that can be converted into biodiesel and used as a substitute for diesel fuel. The seed cake remaining after oil extraction is an excellent source of plant nutrients (Foidl et al., 2001). The level of essential amino acids of the defatted kernel meal of the non-toxic variety are higher than that of FAO reference protein except for lysine (Makkar and Becker, 1999a; Foidl et al., 2001). However the presence of high levels of antinutrients (Table 3) prevent their use in animal feeding. Phorbol esters have been identified as the major toxic principle in jatropha (Makkar and Becker, 1997a). At least six phorbol esters are present in jatropha seeds (Haas and Mittelbach, 2000). The phorbol esters are reported to mimic the action of diacyl glycerol, an activator of protein kinase C, which regulates different signal transduction pathways (Mosior and Newton, 1995). Interference with the activity of protein kinase $\mathrm{C}$ affects a number of processes including, phospholipid and protein synthesis, enzyme activities, DNA synthesis, phosphorylation of proteins, cell differentiation and gene expression. The phorbol esters themselves do not induce tumours but promote tumour growth following exposure to a subcarcinogenic dose of a carcinogen. They can thus be designated as co-carcinogens (Brodie and Blumberg, 2003; Gonzalez-Guerrico and Kazanietz, 2005).

Varieties of jatropha plants where phorbol esters are almost absent have been identified in Mexico. This offers promise for inclusion of products from these plants in animal and fish diets. The chemical composition of the seed meal extracted from the non-toxic variety (from Veracruz, Mexico) appear to be similar/superior to the toxic variety (Cape Verde, Mexico) (Foidl et al., 2001). The non-protein nitrogen formed only $7.8 \%$ to $9.0 \%$ of the total nitrogen in the jatropha meals suggesting the presence of high levels ( $\sim 90 \%$ ) of true protein (Makkar et al., 1998a).

Even though the Mexican non-toxic varieties lack the most potent toxin, phorbol esters, other antinutrients such as trypsin inhibitor, lectin and phytate are present in significant amounts (Table 3), and their levels are similar to those in the toxic varieties. Moist heating of seeds almost completely inactivated trypsin inhibitor activity and decreased lectin activity (Makkar and Becker, 1999a). This heat treatment should have the added benefit of increasing protein digestibility. Moist heating may also make the seed cake from the non-toxic variety usable in fish diet. Heat treated seed meal of the non-toxic variety of $J$. curcas was found to be comparable to commercially available soyabean meal in nutritional quality for common carp (R. Richter, G. Francis and K. Becker, unpublished results). In contrast, heat treatment followed by aqueous methanol extraction to remove phorbol esters could result in elimination of most of the antinutrients and toxins from the toxic variety. The meal treated in this manner was found to be innocuous to rats (Makkar and Becker, 1997b) and fish (unpublished results from our laboratory).

The carp (Cyprinus carpio L.) were found to be highly susceptible to phorbol esters present in the seed meal of

Table 3 Important phytochemicals in seed meal of toxic and non-toxic variety of Jatropha curcas

\begin{tabular}{lcc}
\hline \hline Component & Toxic variety & Non-toxic variety \\
\hline Phorbol esters (mg/g kernel) & 2.79 & 0.11 \\
Total phenols (\% tannic acid equivalent) & 0.36 & 0.22 \\
Tannins (\% tannic acid equivalent) & 0.04 & 0.02 \\
Phytates (\% dry matter) & 9.40 & 8.60 \\
Saponins (\% diosgenin equivalent) & 21.3 & 3.40 \\
Trypsin inhibitor (mg trypsin inhibited per g sample) & 102 & 26.5 \\
Lectins (1/mg of meal that produced haemagglutination per ml of assay medium) & 51
\end{tabular}

All data are on a dry-matter basis; source: Makkar et al. (1998a). 
Effects and applications of phytochemicals

Table 4 Phytochemicals in Jatropha curcas

\begin{tabular}{|c|c|c|c|}
\hline Phytochemical & $\begin{array}{l}\text { Plant } \\
\text { part }\end{array}$ & Activity & Reference \\
\hline Phorbol esters & Seed & $\begin{array}{l}\text { Carcinogenic, irritant, toxic } \\
\text { Pesticidal, insecticidal and molluscicidal }\end{array}$ & $\begin{array}{l}\text { Becker and Makkar, } 1998 \\
\text { Rug and Ruppel, 2000; Mengual, 1997; } \\
\text { Solsoloy and Solsoloy, } 1997\end{array}$ \\
\hline Trypsin inhibitors, lectin, phytate & Seed & $\begin{array}{l}\text { Antinutritional: reduce feed conversion } \\
\text { efficiency, growth }\end{array}$ & $\begin{array}{l}\text { Makkar and Becker, 1997a; Makkar et al. } \\
\text { 1998a }\end{array}$ \\
\hline Jatrophone (a macrocyclic diterpene) & Seed & Antileukemic; platelet aggregation inhibition & Kupchan et al., 1970; Dutra et al., 1996 \\
\hline $\begin{array}{l}\text { Flavonoids: apigenin and its glycosides } \\
\text { vitexin and isovitexin; sterols: } \\
\text { stigmasterol, beta-D-sitosterol and its } \\
\text { beta-D-glucoside }\end{array}$ & Leaves & Anti-inflammatory & Chhabra et al., 1990 \\
\hline Proteolytic enzyme, curcain & Latex & Wound healing properties & Nath and Dutta, 1997 \\
\hline Cyclic octapeptide curcacycline & Latex & Immunomodulatory properties & Van den Berg et al., 1995 \\
\hline
\end{tabular}

the toxic variety of J. curcas. The threshold level at which phorbol esters caused adverse effects was 15 p.p.m. $(15 \mu \mathrm{g} / \mathrm{g})$ in the diet (Becker and Makkar, 1998). Carp could be a useful species for bioassay of phorbol esters, and it has been used regularly in our laboratory for evaluation of various detoxification conditions for making $J$. curcus seed meal safe for introduction in animal diets.

The phorbol esters were also found to be an effective biopesticide against diverse fresh-water snails. Extracts from J. curcas $L$. were found to be toxic against snails transmitting Schistosoma mansoni and S. haematobium (Rug and Ruppel, 2000). Compared with aqueous extract, methanol extract showed the highest toxicity against all organisms that were tested with $\mathrm{LC}_{100}$-values of 25 p.p.m. for cercariae and the snail Biomphalaria glabrata and 1 p.p.m. for the snails Bulinus truncatus and $B$. natalensis. Attenuation of cercariae leading to reduced infectivity in mice could be achieved in concentrations below those exerting acute toxicity. Thus, phorbol esters from the jatropha plant could become an affordable and effective component of an integrated approach to schistosomiasis control (Table 4). Jatropha oil or methanol extract of jatropha oil containing phorbol esters has also been shown to have strong insecticidal effects against Busseola fusca and Sesamia calamistis larvae (Mengual, 1997), and pesticidal effects against Sitophilus zeamays and Callosobruchus chinesis and deterred their oviposition on sprayed corn and mungbeans seeds (Solsoloy and Solsoloy, 1997).

Jatropha leaves are used to cure various diseases. Anti-inflammatory compounds isolated from leaves are flavonoids apigenin and its glycosides vitexin and isovitexin, the sterols stigmasterol, beta-D-sitosterol and its beta-D-glucoside (Chhabra et al., 1990). The jatropha latex has a proteolytic enzyme, curcain, which was found to have better properties for healing wounds than nitrofurazone (Nath and Dutta, 1997). A novel cyclic octapeptide (GlyLeu-Leu-GlyThr-Val-Leu-Leu-Gly), curcacycline, has also been isolated from jatropha latex. This cyclic octapeptide has been shown to inhibit classical pathway activity of human complement, and proliferation of human T-cells (Van den Berg et al., 1995).

Both moringa and jatropha seeds are good sources of phytate (Makkar and Becker, 1997c and 1999a). Several beneficial effects of phytate including cancer prevention, reduction in iron-induced oxidative injury and reversal of initiation of colorectal tumorigenesis, and prevention of lipid peroxidation have been reported (Singh et al., 2003).

\section{Lesser-known legumes}

Extensive research efforts are being directed to identify and evaluate under-utilised sources, including tribal pulses and other legumes, because they are well adapted to adverse environmental conditions and are resistant to diseases and pests. These could form a good source of protein for both human and livestock and could also be a source of bioactive compounds (Table 5).

Entada phaseoloides Merrill (gila bean) is widely distributed throughout the tropics. In India, ground seeds are taken internally for a variety of remedies, including contraception, snake bites and as aphrodisiacs. Villagers also use it as a natural shampoo and as a fish poison. A systematic study in our laboratory on nutritional quality and antinutrient properties of $E$. phaseoloides seeds showed that they have three times the activity of trypsin inhibitor compared with soya bean and a high level of saponins. This explains the use of these seeds as fish poison. The lethal concentration $\left(50 \% ; \mathrm{LC}_{50}\right.$ ) of saponins extracted from gila beans for fish was $2.5 \mathrm{mg} / 100 \mathrm{ml}$ water; whereas at this concentration of quillaja saponins no mortality was observed (Siddhuraju et al., 2001 and 2004). In north-east India, the tribal people soak the seeds and then boil or roast them before eating. Soaking and removal of water is expected to remove saponins and the heat treatment would inactivate trypsin inhibitor activity. From E. africana roots, Cioffi et al. (2006) isolated and characterised nine new triterpenoid ester saponins having echinocystic acid and acacia acid as aglycon. Moderate to high cytotoxic potency 
Makkar, Francis and Becker

Table 5 Bioactive compounds in lesser-known legumes

\begin{tabular}{|c|c|c|}
\hline Legume & Bioactive compounds & Reference \\
\hline Entada phaseoloides beans & Trypsin inhibitor, saponins & Siddhuraju et al., 2001 and 2004 \\
\hline Entanda africana roots & Triterpenoid ester saponins having antiproliferative activity & Cioffi et al., 2006 \\
\hline Sesbania aculeate seeds & Non-starch polysaccharides, mainly galactomannan & Hossain et al., 2001 and 2003 \\
\hline Mucuna pruriens seeds & L-3,4-dihydroxyphenylalanine, non-starch polysaccharides & Siddhuraju and Becker, 2001b and 2002 \\
\hline Cassia fistula stem bark and leaves & $\begin{array}{l}\text { Phenolic compounds as antioxidants and antimicrobial } \\
\text { components }\end{array}$ & Siddhuraju et al., 2002; Kumar et al., 2006 \\
\hline $\begin{array}{l}\text { Canavalia ensiformis, C. gladiata, } \\
\text { C. virosa seeds }\end{array}$ & Trypsin inhibitor, lectin, canavanine & Siddhuraju and Becker, 2001c \\
\hline
\end{tabular}

against epithelial kidney cell lines was found for almost all compounds isolated. On the other hand, triterpene saponins, designated as pursethosides, isolated from seed kernel from $E$. pursaetha were found to be non-cytoxic when tested against human colon cells (Tapondjou et al., 2005).

Fish meal, the conventional protein source in fish feeds, is scarce and expensive, particularly in developing countries. Legume seeds have been investigated as an alternative source of protein to fish meal. However, the extent to which legume seeds can be used is limited due to the presence of various antinutrients and deficiency of sulphur-containing amino acids. Presence of high levels of non-starch polysaccharides (NSPs) in legumes could be a major constraint in the utilisation of legumes in fish diets. Studies conducted in our laboratory confirmed that Sesbania aculeate endosperm $(30 \%$ of whole seed) at a level of $5.8 \%$ or higher ( $75 \%$ of which is NSP galactomannan) reduced growth and nutrient utilisation in tilapia (Oreochromis niloticus). This was due to an increase in the viscosity of the intestinal contents (Hossain et al., 2003). S. aculeate is a leguminous crop widely available in many tropical countries of Asia and Africa. Lower body lipid content and lower muscle and plasma cholesterol levels in common carp fed galactomannan-rich endosperm of $S$. aculeate seeds has also been reported. This effect could also be due to the NSPs (Hossain et al., 2001).

Velvet bean (Mucuna pruriens var. utilis) is another under-utilised legume that is widespread throughout the tropics. The seeds of velvet beans are rich $(4.3 \%$ to $4.8 \%)$ in the non-protein amino acid L-DOPA (L-3,4-dihydroxyphenylalanine) and it could be extracted for providing symptomatic relief in Parkinson's disease (Siddhuraju and Becker, 2001a and 2005). In another study, the effect of addition of L-DOPA in the diets of common carp (Cyprunus carpio L.) demonstrated that its incorporation at up to $0.7 \%$ in the diet did not affect growth performance and feed utilisation. On the other hand, higher levels, $1.4 \%, 2.8 \%$ and $5.6 \%$ of L-DOPA decreased feed conversion ratio significantly, protein efficiency ratio and apparent net protein utilisation and increased oxygen consumption per unit body weight gain. None of the fish died even at a level as high as $5.6 \%$ of L-DOPA in the diet (Siddhuraju and Becker, 2002). Histopathological and biochemical studies need to be done on fish fed L-DOPA before addition of mucuna seeds as a replacement for fish meal could be advocated in aquaculture production systems. Fish (common carp) fed diets containing $20 \%$ or more of the autoclaved mucuna meal produced adverse effects. These effects were ascribed to the presence of heat-stable antinutrients such as L-DOPA and NSPs in mucuna meal (Siddhuraju and Becker, 2001b).

Different parts of another lesser-known legume, Cassia fistula (Indian laburnum) were investigated for antioxidant activity. This legume is considered to have good medicinal value. The aqueous alcoholic extracts of stems, bark and leaves showed high antioxidant activity, which was attributed to phenolic compounds. Fruit pulp and flowers had low antioxidant activity (Siddhuraju et al., 2002).

The seeds of Canavalia ensiformis, C. gladiata and C. virosa, after boiling, are consumed by tribal people in south India. Canavalia spp. have desirable agronomic features enabling them to grow well in tropical conditions of high temperature and low soil moisture; and these are pest and disease resistant. These are also grown as cover, green manure and fodder crop. The seeds of Canavalia spp. contain trypsin inhibitor and lectins, which are destroyed by heat treatment. Canavanine, a heat-stable non-protein amino acid, is also present at $3 \%$ (on a dry-matter basis), which causes many adverse effects in monogastrics (Siddhuraju and Becker, 2001c).

Quinolizidine alkaloids constitute an important group of natural products in the Fabaceae, and they act as a chemical defence against phytophagous animals (nematodes, molluscs, insects, vertebrates), micro-organisms (viruses, bacteria, fungi) and other competing plant species. Lupin seeds contain up to $8 \%$ quinolizidine alkaloids, which limit the utilisation of these seeds as human food or in animal diets. Lupanine and sparteine, two alkaloids present in lupin, decreased substantially the gas production and true digestibility of feed in a simulated in vitro rumen fermentation system. In addition, these alkaloids were not degraded by rumen microbes, suggesting their adverse effects both at rumen and postrumen levels (Aguiar et al., 1998).

\section{Future areas of work and challenges}

Plants produce an amazing variety of metabolites with diverse properties. From the above discussion, it is evident 
that the plants and/or natural plant products that can be used as growth promoters for ruminant and fish species could provide valid alternatives to synthetic compounds. Some of the research activities and novel methodologies developed have opened up several avenues for future studies and applications of plants or plant-based products, which could have important ramifications in livestock and aquaculture production systems.

The plant secondary metabolites are generally associated with plant defence, but have also been associated with a wide range of biological properties. The concentrations of plant secondary metabolites and their activities in biological systems vary with maturity of the plant and plant parts, in addition to soil conditions, water and light availability and other environmental conditions in which the plant is growing. Levels of secondary metabolites are both environmentally induced as well as genetically controlled. In addition, the structure and activity of active moieties in a group of one class of plant secondary metabolites, for example, tannins, saponins or alkaloids also change with environmental condition and maturity stages of the plant. This poses an enormous problem in the use of plants or plant products in industries, whether it is livestock, food or the cosmetic industry, because of batch-to-batch variation in the product quality. This calls for the availability of a simple but robust bioassay, which can be used with little resources and in a short time to evaluate the quality of the product, based on the property for which it will be used. It is good to have information on the active moieties (and possibly their structure) in the product responsible for the biological effects of interest; however, it is not indispensable for exploiting it for industrial and nutritional applications. A robust bioassay could enable the estimation of the biological activity of a batch/product in a defined unit, and different batches could be harmonised to produce a product containing the same number of units every time. Another challenge, particularly for ruminants, would be to beat the microbial adaptation and develop supplementation strategies to obtain persistent effects.

Additionally, there is an urgent need to bridge the wide gap existing between phytochemists, rumen microbiologists and animal scientists, and establish and promote collaboration between them. This would enable not only the isolation and purification of the active moieties from plants of interest but also the study of structure-activity relationships and phytochemical-phytochemical interactions and the exploitation of the active compounds in practical feeding and management situations. Equally important is to integrate the use of plants containing bioactive compounds in livestock and aquaculture production systems for enhancing their efficiency and making them environment friendly and sustainable.

\section{References}

Abreu A, Carulla JE, Lascano CE, Diaz TE, Kreuzer M and Hess HD 2004. Effects of Sapindus saponaria fruits on rumen fermentation and duodenal nitrogen flow of sheep fed a tropical grass diet with and without legume. Journal of Animal Science 82, 1392-1400.

Aguiar R, Wink M, Makkar HPS, Blümmel M and Becker K 1998. Effects of Lupinus alkaloids on in vitro rumen fermentation and their fate in the rumen. In Recent advances of research in antinutritional factors in legume seeds and rapeseed (ed. AJM Jansman, GD Hill, J Huisman and AFB van der Poel), EAAP publication no. 93, pp. 179-182. Wageningen Press, The Netherlands.

Akbar MA and Ahmed TU 2006. Improving animal productivity and reproductive efficiency: development and testing medicated urea-molasses multi-nutrient blocks in rural farms of Bangladesh. IAEA-TECDOC 1495, pp. 13-27. IAEA, Vienna, Austria.

Akkari $\mathrm{H}$, Dargouth MA, Ben Salem $\mathrm{H}$ and Abidi S 2007. Feeding Acacia cyanophylla Lindl. foliage to Barbarine lambs reduces the excretion of gastrointestinal nematode eggs. Animal Feed Science and Technology, in press.

Al-Habori M and Raman A 1998. Review: antidiabetic and hypocholesterolaemic effects of fenugreek. Phytotherapy Research 12, 233-242.

Annuk H, Hormo S, Turi E, Mikelsaar M, Arak E and Wadstrom T 1999. Effect of cell surface hydrophobicity and susceptibility of Helicobacter pylori to medicinal plant extracts. FEMS Microbiology Letters 172, 41-45.

Asres K, Bucar F, Edelsbrunner S, Kartnig T, Hoger G and Theil W 2001. Investigations on antimycobacterial activity of some Ethiopian medicinal plants. Phytotherapy Research 15, 323-326.

Attwood G, Li D, Pacheco D and Tavendale M 2006. Production of indolic compounds by rumen bacteria isolated from grazing ruminants. Journal of Applied Microbiology 100, 1261-1271.

Barry TN and McNabb WC 1999. The implications of condensed tannins on the nutritive value of temperate forages fed to ruminants. British Journal of Nutrition 81, 263-272.

Becker K and Makkar HPS 1998. Effects of phorbol esters in carp (Cyprinus carpio L). Veterinary and Human Toxicology 40, 82-86.

Becker K and Makkar HPS 1999. Effects of dietary tannic acid and quebracho tannin on growth performance and metabolic rates of common carp (Cyprinus carpio L.). Aquaculture 175, 327-335.

Benie T, El-Izzi A, Tahiri C, Duval J and Thieulant ML 1990. Combretodendron africanum bark extract as an antifertility agent. I. Estrogenic effects in vivo and LH release by cultured gonadotrope cells. Journal of Ethnopharmacology 29, 13-23.

Bennet-Jenkins E and Bryant C 1996. Novel sources of anthelmintics. International Journal for Parasitology 26, 937-947.

Bennett RN, Mellon FA, Foidl N, Pratt JH, DuPont MS, Perkins L and Kroon PA 2003. Profiling glucosinolates and phenolics in vegetative and reproductive tissues of the multi-purpose trees Moringa oleifera L. (Horseradish tree) and Moringa stenopetala L. Journal of Agricultural and Food Chemistry 51, 3546-3553.

Ben Salem H, Makkar HPS, Nefzaoui A, Hassayou L and Abidi S 2005. Benefit from the association of small amounts of tannin-rich shrub foliage (Acacia cyanophylla Lindl.) with soya bean meal given as supplements to Barbarine sheep fed on oaten hay. Animal Feed Science Technology 122, 173-186.

Bhatta R, Krishnamoorthy $U$ and Mohammed F 2000. Effect of feeding tamarind (Tamarindus indica) seed husk as a source of tannin on dry matter intake, digestibility of nutrients and production performance of crossbred dairy cows in mid-lactation. Animal Feed Science Technology 83, 67-74.

Bhatta R, Shinde AK, Vaithiyanathan S, Sankhyan SK and Verma DL 2002. Effect of polyethylene glycol-6000 on nutrient intake, digestion and growth of kids browsing Prosopis cineraria. Animal Feed Science Technology 101, 45-54.

Brodie C and Blumberg PM 2003. Regulation of cell apoptosis by protein kinase C. Apoptosis 8, 19-27.

Bureau DP, Harris AM and Cho CY 1998. The effects of purified alcohol extracts from soy products on feed intake and growth of chinook salmon (Oncorhynchus tshawytscha) and rainbow trout (Oncorhynchus mykiss). Aquaculture 161, 27-43.

Chhabra SC, Mahunnah RL and Mshiu EN 1990. Plants used in traditional medicine in eastern Tanzania III. Angiosperms (Euphorbiaceae to Menispermaceae). Journal of Ethnopharmacology 28, 255-283.

Chen J-C and Chen K-W 1997. Oxygen uptake and ammonia-N excretion of juvenile Penaeus japonicus during depuration following one-day exposure to different concentrations of saponin at different salinity levels. Aquaculture 156, 77-83. 
Cioffi G, Dal Piaz F, De Caprariis P, Sanogo R, Marzocco S, Autore G and De Tommasi N 2006. Antiproliferative triterpene saponins from Entada africana. Journal of Natural Products 69, 1323-1329.

Conrad J, Vogler B, Reeb S, Klaiber I, Papjewski S, Roos G, Vasquez E, Setzer MC and Kraus W 2001. Isoterchebulin and 4,6-0-isoterchebuloyl-D-glucose, novel hydrolysable tannins from Terminalia macroptera. Journal of Natural Products 64, 294-299.

Daing T and Win YT 2006. Evaluation of urea molasses mineral blocks as a feed supplement for cattle production and as a carrier for anthelmintic medication in Myanmar. IAEA-TECDOC 1495, pp. 77-90. IAEA, Vienna, Austria.

Daxenbichler ME, Spencer GF, Carlson DG, Rose GB, Brinker AM and Powell RG 1991. Glucosinolate composition of seeds from 297 species of wild plants. Phytochemistry 30, 2623-2638.

Denman SE and McSweeney CS 2005. Quantitative (real-time) PCR. In Methods in gut microbial ecology for ruminants (ed. HPS Makkar and CS McSweeney), pp. 105-108. Springer, Dordrecht, The Netherlands.

Díaz A, Avendaño M and Escobar A 1993. Evaluation of Sapindus saponaria as a defaunating agent and its effects on different ruminal digestion parameters. Livestock Research for Rural Development 5, 1-6.

Djipa CD, Delmée M and Quetin-Leclercq J 2000. Antimicrobial activity of bark extracts of Syzygium jambos (L.) Aston (Myrtaceae). Journal of Ethnopharmacology 71, 307-313.

Doan DV, Nguyen VT, Nguyen NT and Ha TKL 2006. Development of ureamolasses multi-nutrient block (UMMB) and medicated UMMB (MUMB) for ruminants in Vietnam. IAEA-TECDOC 1495, pp. 139-150IAEA, Vienna, Austria.

Dohme F, Machmüller A, Estermann BL, Pfister P, Wasserfallen A and Kreuzer $M$ 1999. The role of the rumen ciliate protozoa for methane suppression caused by coconut oil. Letters in Applied Microbiology 29, 187-192.

Dohme F, Machmüller A, Wasserfallen A and Kreuzer M 2001. Ruminal methanogenesis as influenced by individual fatty acids supplemented to complete ruminant diets. Letters in Applied Microbiology 32, 47-51.

Dutra FV, Calixto JB, Medeiros YS and Brum R 1996. Jatrophone inhibits platelet rich plasma aggregation from man, rat and guinea-pig induced by different agents. Phytotherapy Research 10, 271-273.

Estrella MCP, Mantaring JBV and David GZ 2000. A double-blind, randomized controlled trial on the use of malunggay (Moringa oleifera) for augmentation of the volume of breastmilk among non-nursing mothers of preterm infants. The Philippine Journal of Pediatric 49, 3-6.

Fahey JW, Zalcmann AT and Talalay P 2001. The chemical diversity and distribution of glucosinolates and isothiocyanates among plants. Phytochemistry 56, 5-51[Corrigendum: Phytochemistry 59 (2002) 237].

Fahey JW, Haristoy X, Dolan PM, Kensler TW, Scholtus I, Stephenson KK, Talalay $P$ and Lozniewski A 2002. Sulforaphane inhibits extracellular, intracellular, and antibiotic-resistant strains of Heliobacter pylori and prevents benzo[a]pyrene-induced stomach tumors. Proceedings of the National Academy of Sciences of the United States of America 99, 7610-7615.

Faizi S, Siddiqui BS, Saleem R, Noor F and Husnain S 1997. Isolation and structure elucidation of a novel glycoside niazidin from pods of Moringa oleifera. Journal of Natural Products 60, 1317-1321.

Flaoyen A, Wilkins AL and Sandvik M 2004. The metabolism of saponins from Yucca schidigera in sheep. In Poisonous plants and related toxins (ed. T Acamovic, CS Stewart and TW Pennycott), pp. 210-214. CABI Publishing, Wallingford, UK.

Foidl N, Makkar HPS and Becker K 2001. The potential of Moringa oleifera for agricultural and industrial uses. In The miracle tree: the multiple attributes of Moringa (ed. LJ Fuglie), pp. 45-76. CTA Publication, Wageningen, The Netherlands.

Francis G, Makkar HPS and Becker K 2001a. Antinutritional factors present in plant-derived alternate fish feed ingredients and their effects in fish. Aquaculture 199, 197-227.

Francis G, Makkar HPS and Becker K 2001b. Effects of quillaja saponins on growth, metabolism, egg production, and muscle cholesterol in individually reared Nile tilapia (Oreochromis niloticus). Comparative Biochemistry and Physiology Part C: Toxicology and Pharmacology 129, 105-114.

Francis G, Makkar HPS and Becker K 2002a. Dietary supplementation with a quillaja saponin mixture improves growth performance and metabolic efficiency in common carp (Cyprinus carpio L.). Aquaculture 203, 311-320.
Francis G, Makkar HPS and Becker K 2002b. Effects of cyclic and regular feeding of quillaja saponin supplemented diet on growth and metabolism of common carp (Cyprinus carpio L.). Fish Physiology and Biochemistry 24, 343-350.

Francis G, Levavi-Sivan B, Avitan A and Becker K 2002c. Effects of long term feeding of quillaja saponins on sex ratio, muscle and serum cholesterol and $\mathrm{LH}$ levels in Nile tilapia (Oreochromis niloticus (L.)). Comparative Biochemistry and Physiology Part C: Toxicology and Pharmacology 133, 593-603.

Francis G, Kerem Z, Makkar HPS and Becker K 2002d. The biological action of saponins in animal systems: a review. British Journal of Nutrition 88, 587-605.

Fuglie LJ 2001. Natural nutrition for the tropics. In The miracle tree: the multiple attributes of Moringa (ed. LJ Fuglie), pp. 103-115. CTA Publication, Wageningen, The Netherlands

Garg SK, Makkar HPS, Nagal KB, Sharma SK, Wadhwa DR and Singh B 1992. Toxicological investigations into oak (Quercus incana) leaf poisoning in cattle. Veterinary and Human Toxicology 34, 161-164.

Ghasi S, Nwobodo E and Ofili JO 2000. Hypocholesterolemic effects of crude extract of leaf of Moringa oleifera Lam in high-fat diet fed Wister rats. Journal of Ethnopharmacology 69, 21-25.

Githiori JB, Höglund J, Waller PJ and Baker RL 2004. Evaluation of anthelmintic properties of some plants used as livestock dewormers against Haemonchus contortus infections in sheep. Parasitology 129, 245-253.

Goel G, Makkar HPS and Becker K 2007. Effect of saponin-rich fractions of different plants on rumen fermentation with particular reference to methane emission in vitro. Proceedings of the Society of Nutrition Physiology 16, 84 (abstract).

Gonzalez-Guerrico AM and Kazanietz MG 2005. Phorbol ester-induced apoptosis in prostate cancer cells via autocrine activation of the extrinsic apoptotic cascade: a key role for protein kinase C. The Journal of Biological Chemistry 280, 38982-38991.

Gupta R, Kannan GM, Sharma M and Flora SJS 2005. Therapeutic effects of Moringa oleifera on arsenic-induced toxicity in rats. Environmental Toxicology and Pharmacology 20, 456-464.

Hagerman AE, Riedl KM and Rice RE 1999. Tannins as biological antioxidants. In Plant polyphenols 2: Chemistry, biology, pharmacology, ecology (ed. GG Gross, RW Hemingway and T Yoshida), pp. 495-505. Kluwer Academic Publishers/Plenum Press, Dordrecht/New York.

Haristoy X, Fahey JW, Scholtus I and Lozniewski A 2005. Evaluation of antimicrobial effect of several isothiocyanates on Helicobacter pylori. Planta Medica 71, 326-330.

Haas W and Mittelbach M 2000. Detoxification experiments with seed oil from Jatropha curcas L. Industrial Crops and Products 12, 111-118.

Heller J. 1996. Physic nut. Jatropha curcas L. Promoting the conservation and use of underutilzed and neglected crops. 1. Institute of Plant Genetics and Crop Plant Research. Gatersleben/ International Plant Genetic Resources Research Institute, Rome, Italy. Retrieved July 3, 2001 from http:// www.ipgri.cgiar.org/publications/pdf/161.pdf.

Hess HD, Kreuzer M, Diaz TE, Lascano CE, Carulla JE, Soliva CR and Machmüller A 2003a. Saponin rich tropical fruits affect fermentation and methanogenesis in faunated and defaunated rumen fluid. Animal Feed Science and Technology 109, 79-94.

Hess HD, Monsalve LM, Lascano CE, Carulla JE, Diaz TE and Kreuzer M 2003b. Supplementation of a tropical grass diet with forage legumes and Sapindus saponaria fruits: effects on in vitro ruminal nitrogen turnover and methanogenesis. Australian Journal of Agricultural Research 54, 703-713.

Hess HD, Beuret RA, Lötscher M, Hindrichsen IK, Machmüller A, Carulla JE, Lascano CE and Kreuzer M 2004. Ruminal fermentation, methanogenesis and nitrogen utilization of sheep receiving tropical grass hay-concentrate diets offered with Sapindus saponaria fruits and Cratylia argentea foliage. Animal Science 79, 177-189.

Ho KY, Tsai CC, Huang JS, Chen CP, Lin TC and Lin CC 2001. Antimicrobial activity of tannin components from Vaccinium vitis-idaea L. Journal of Pharmacy and Pharmacology 53, 187-191.

Hoffmann EM, Muezel S and Becker K 2003. Effects of Moringa oleifera seed extract on rumen fermentation in vitro. Archiv für Tierernährung 57, 65-81.

Hossain MA, Focken U and Becker K 2001. Galactomannan-rich endosperm of Sesbania (Sesbania aculeate) seeds responsible for retardation of growth and feed utilisation in common carp, Cyprinus carpio L. Aquaculture 203, 121-132. 
Hossain MA, Focken $U$ and Becker K 2003. Antinutritive effects of galactomannan-rich endosperm of Sesbania (Sesbania aculeate) seeds on growth and feed utilization in tilapia, Oreochromis niloticus. Aqualculture Research 34, 1171-1179.

Hristov AN, McAllister A, Van Herk FH, Cheng KJ, Newbold CJ and Cheeke PR 1999. Effect of Yucca schidigera on rumen fermentation and nutrient digestion in heifers. Journal of Animal Science 77, 2554-2563.

Hussain MG, Kohinoor AHM, Islam MS, Hossain MA, Dey MM and Mazid MA 2000. Growth and production performances of GIFT strain of Nile Tilapia, Oreochromis Niloticus L., in ponds and cages under different farming conditions in Bangladesh. Journal of Aquaculture in the Tropics 153, 273-280. Ivan M, Koenig KM, Teferedegne B, Newbold CJ, Entz T, Rode LM and Ibrahim M 2004. Effect of the dietary Enterolobium cyclocarpum foliage on the population dynamics of rumen ciliate protozoa in sheep. Small Ruminant Research 52, 81-91.

Kahn LP and Diaz-Hernandez A 2000. Tannins with anthelmintic properties. In Tannins in Livestock and Human Nutrition (ed. JD Brooker), pp. 140-149. ACIAR Proceedings no. 92, Australia.

Krogdahl A, Roem A and Baeverfjord G 1995. Effects of soybean saponin raffinose and soybean alcohol extract on nutrient digestibilities, growth and intestinal morphology in Atlantic salmon. In Quality in aquaculture (ed. N Svennevig and A Krogdahl), European Aquaculture Society special publicatioon no. 23, pp. 118-119. European Aquaculture Society, Gent, Belgium.

Kupchan SM, Sigel MJ, Matz JA, Renauld JAS, Haltiwanger RC and Bryan RF 1970. Jatrophone, a novel macrocyclic diterpeniod tumorinhibitor from Jatropha gossypiifolia. Journal of the American Chemical Society 92, 4476-4477.

Kumar VP, Chauhan NS, Padh H and Rajani M 2006. Search for antibacterial and antifungal agents from selected Indian medicinal plants. Journal of Ethnopharmacology 107, 182-188.

Lila ZA, Mohammed N, Kanda S, Kamada T and Itabashi H 2003. Effect of sarsaponin on ruminal fermentation with particular reference to methane production in vitro. Journal of Dairy Science 86, 3330-3336.

Liu JY, Yuan WZ, Ye J and Wu Y 2003. Effect of tea (Camellia sinensis) saponin addition on rumen fermentation in vitro. In Matching herbivore nutrition to ecosystems biodiversity. Tropical and subtropical agrosystems (ed. JH Camacho and CAS Castro), pp. 561-564. Autonomous University of Yucatan, Mexico.

Lorimer SD, Perry NB, Foster LM and Burgess EL 1996. A nematode larval motility inhibition assay for screening plant extracts and natural products. Journal of Agricultural and Food Chemistry 44, 2482-2845.

Machmüller A, Ossowski DA and Kreuzer M 2000. Comparative evaluation of the effects of coconut oil, oilseeds and crystalline fat on methane release, digestion and energy balance in lambs. Animal Feed Science and Technology $85,41-60$.

McNeill DM, Osborne N, Komolong M and Nankervis D 1998. Condensed tannins in the Leucaena genus and their nutritional sugnificance for ruminants. In Leucaena - adaptation, quality and farming systems (ed. HM Shelton, RC Gutteridge, BF Mullin and RA Bray), pp. 205-214. ACIAR proceedings no. 86, Australia.

McNeill DM, Komolong M, Gobiun N and Barber D 2000. Influence of dietary condensed tannins on microbial crude protein supply in sheep. In Tannins in Livestock and Human Nutrition (ed. JD Brooker), pp. 57-61. ACIAR Proceedings no. 92, Australia.

McSweeney CS, Palmer B, McNeil DM and Krause DO 2001. Microbial interactions with tannins: nutritional consequences for ruminants. Animal Feed Science and Technology 91, 83-93.

McSweeney CS, Makkar HPS and Reed JD 2003. Modification of rumen fermentation for detoxification of harmful compounds. Proceedings of international symposium on nutrition of herbivores, 20-24 October, Merida, Yucatan, Mexico, pp. 239-270.

Makkar HPS 2000. Roles of tannins and saponins. In Effects of antinutrients on the nutritional value of legume dietsvol. 8COST 98 (ed. A Krogdahl, SD Mathiesen and IF Pryme), pp. 103-114. European Union, Brussels, Belgium.

Makkar HPS 2003. Effects and fate of tannins in ruminant animals, adaptation to tannins, and strategies to overcome detrimental effects of feeding tanninrich feeds. Small Ruminant Research 49, 241-256.

Makkar HPS 2005. In vitro gas method for evaluation of feeds containing phytochemicals-a review. Animal Feed Science and Technology 123-124, 291-302.
Makkar HPS 2006. Improving animal productivity through meeting nutrient deficiencies with multinutrient blocks, enhancing utilization efficiency of alternate feed resources, and controlling internal parasites: a summary. IAEA-TECDOC 1495, pp. 1-9. IAEA, Vienna, Austria.

Makkar HPS and Becker K 1997a. Jatropha curcas toxicity: identification of toxic principle (s). In Toxic plants and other natural toxicants (ed. T Garland and AC Barr), pp. 554-558. CAB International, New York.

Makkar HPS and Becker K 1997b. Potential of Jatropha seed meal as a protein supplement to livestock feed and constraints to its utilisation. Proceedings of Jatropha 97: International symposium on biofuel and industrial products from Jatropha curcas and other tropical oil seed plants, 23-27 February 1997, Managua, Nicaragua.

Makkar HPS and Becker K 1997c. Nutrients and antiquality factors in different morphological parts of the Moringa oleifera tree. Journal of Agricultural Science, Cambridge 128, 311-322.

Makkar HPS and Becker K 1998. Moringa oleifera seed meal and proteins on rumen fermentation in vitro. Annual report. Institute for Animal Production in the Tropics and Subtropics, University of Hohenheim, Stuttgart, Germany.

Makkar HPS and Becker K 1999a. Plant toxins and detoxification methods to improve feed quality of tropical seeds - Review. Asian-Australian Journal of Animal Science 12, 467-480.

Makkar HPS and Becker K 1999b. Nutritional studies on rats and fish (carp Cyprinus carpio) fed diets containing unheated and heated Jatropha curcas meal of a non-toxic provenance. Plant Foods for Human Nutrition 53, 183-192.

Makkar HPS and Becker K 2000. Beneficial effects of saponins on animal production. In Saponins in food and feedstuffs and medicinal plants (ed. W Oleszek and A Marston), pp 281-286. Kluwer Academic Publishers, Dordrecht, The Netherlands.

Makkar HPS and McSweeney CS 2005. Methods in gut microbial ecology for ruminants. Springer, Dordrecht, The Netherlands.

Makkar HPS, Blümmel M and Becker K 1995a. In vitro effects and interactions of tannins and saponins and fate of tannins in rumen. Journal of the Science of Food and Agriculture 69, 481-493.

Makkar HPS, Becker K, Abel HJ and Szegletti C 1995b. Degaradation of condensed tannins by rumen microbes exposed to quebracho tannins (QT) in rumen simulation technique (RUSITEC) and effects of QT on fermentation processes in the RUSITEC. Journal of the Science of Food and Agriculture 69, 495-500.

Makkar HPS, Aderibigbe AO and Becker K 1998a. Comparative evaluation of non-toxic and toxic varieties of Jatropha curcas for chemical composition, digestibility, protein degradability and toxic factors. Food Chemistry 62, 207-215.

Makkar HPS, Sen S, Blümmel M and Becker K 1998b. Effects of fractions containing saponins from Yucca schidigera, Quillaja saponaria and Acacia auriculoformis on rumen fermentation. Journal of Agricultural and Food Chemistry 46, 4324-4328.

Makkar HPS, Aregheore EM and Becker K 1999. Effect of saponins and plant extracts containing saponins on the recovery of ammonia during ureaammoniation of wheat straw and fermentation kinetics of the treated straw. Journal of Agricultural Science, Cambridge 132, 313-321.

Mekonnen $Y$ and Dräger B 2003. Glucosinolates in Moringa stenopetala. Planta Medica 69, 380-382.

Mengual L 1997. Extraction of bioactive substances from Jatropha curcas L. and bioassays on Zonocerus variegatus, Sesamia calamistis and Brusseola fusca for characterisation of insecticidal properties. In Biofuels and industrial products from Jatropha curcas (ed. GM Gübitz, M Mittelbach and M Trabi). Dbv-Verlag für Technische Universität Graz, Graz, Austria.

Min BR, Barry TN, Attwood GT and McNabb WC 2003. The effect of condensed tannins on the nutrition and health of ruminants fed fresh temperate forages: a review. Animal Feed Science and Technology 106, 3-19.

Mosior M and Newton AC 1995. Mechanism of interaction of protein kinase C with phorbol esters. Reversibility and nature of membrane association. The Journal of Biological Chemistry 270, 25526-25533.

Muetzel S, Hoffmann EM and Becker K 2003. Supplementation of barley straw with Sesbania pachcarpa leaves in vitro: effects on fermentation variables and rumen microbial concentration structure quantified by ribosomal RNA-targeted probes. British Journal of Nutrition 89, 445-453. 
Muetzel S, Akpagloh R and Becker K 2005. Sapindus rarak saponins do not affect rumen protein degradation in vitro. Proceedings of the Society of Nutrion and Physiology 14, 17 (abstract).

Nair AGR and Subramanian SS 1962. Pigments of the flowers of Moringa pterygosperma. Current Science 31, 155-156.

Nath LK and Dutta SK 1997. Acute toxicity studies and wound healing response of curcain, a proteolytic enzyme extracted from latex of Jatropha curcas Linn. In Biofuels and industrial products from Jatropha curcas (ed. GM Gübitz, M Mittelbach and M Trabi), pp. 82-86. Dbv-Verlag für Technische Universität Graz, Graz, Austria.

Newbold CJ, El Hassan SM, Wang JM, Ortega ME and Wallace RJ 1997. Influence of foliage from African multipurpose trees on activity of rumen protozoa and bacteria. British Journal of Nutrition 78, 237-249.

Ningrat RWS, Garnsworthy PC and Newbold CJ 2002. Saponin fractions in Sapindus rarak: effects on rumen microbes. Reproduction Nutrition Development 42 (suppl. 1), S82.

Nsahlai IV, Umunna NN and Osuji PO 1999. Influence of feeding sheep on oilseed cake following the consumption of tanniniferous feeds. Livestock Production Science 60, 59-69.

Odenyo AA, Osuji PO and Karanfil 0 1997. Effect of multipurpose tree (MPT) supplements on ruminal ciliate protozoa. Animal Feed Science and Technology 67, 169-180.

Pal S, Mukherjee K and Saha BP 1995. Studies on the antiulcer activity of Moringa oleifera leaf extract on gastric ulcer models in rats. Phytotherapy Research 9, 463-465.

Pandian TJ and Sheela SG 1995. Hormonal induction of sex reversal in fish. Aquaculture 138, 1-22.

Pen B, Sar C, Mwenya B, Kuwaki K, Morikawa R and Takahashi J 2006. Effects of Yucca schidigera and Quillaja saponaria extracts on in vitro ruminal fermentation and methane emission. Animal Feed Science and Technology 129, 175-186.

Pen B, Takaura K, Yamaguchi S, Asa R and Takahashi J 2007. Effects of Yucca schidigera and Quillaja saponaria with or without <beta>1-4 galactooligosaccharides on ruminal fermentation, methane production and nitrogen utilization in sheep. Animal Feed Science and Technology, in press.

Petit P, Sauvaire Y, Ponsin G, Manteghetti M, Fave A and Ribes G 1993. Effects of a fenugreek seed extract on feeding behaviour in the rat: metabolic-endocrine correlates. Pharmacology Biochemistry and Behavior 45, 369-374.

Perchellet EM, Moutaseb HU, Makkar HPS and Perchellet P 1996. Ability of tannins extracted from various tree leaves to inhibit the biomarkers of tumor promotion in mouse skin in vivo. International Journal of Oncology 9, 801-809.

Priolo A, Waghorn GG, Lanza M, Biondi L and Pennisi P 2000. Polyethylene glycol as a means for reducing the impact of condensed tannins in carob pulp: effects on lamb growth performance and meat quality. Journal of Animal Science 78, 810-816.

Priolo A, Ben Salem H, Atti N and Nefzaoui A 2002a. Polyethylene glycol in concentrate or feedblocks to deactivate condensed tannins in Acacia cyanophylla Lindl. foliage 2. Effects on meat quality of Barbarine lambs. Animal Science 75, 137-140.

Priolo A, Lanza M, Bella M, Pennisi P, Fasone V and Biondi L 2002b. Reducing the impact of condensed tannins in a diet based on carob pulp using two levels of polyethylene glycol: lamb growth, digestion and meat quality. Animal Research 51, 305-313.

Priolo A, Bella M, Lanza M, Galofaro V, Biondi L, Barbagallo D, Ben Salem H and Pennisi P 2005. Carcass and meat quality of lambs fed fresh sulla (Hedysarum coronarium L.) with or without polyethylene glycol or concentrate. Small Ruminant Research 59, 281-288.

Riedl KM, Carando S, Alessio HM, McCarthy M and Hagerman AE 2002. Antioxidant activity of tannins and tannin-protein complexes: assessment in vitro and in vivo. American Chemical Society Symposium Series 807, 188-200.

Roy PK and Munshi JD 1989. Effect of saponin extracts on oxygen uptake and haematology of an air-breathing climbing perch, Anabas testudineus (Bloch). Journal of Freshwater Biology 1, 167-172.

Roy PK, Munshi JD and Dutta HM 1990. Effect of saponin extracts on morphohistory and respiratory physiology of an air breathing fish, Heteropneustes fossilis (Bloch). Journal of Freshwater Biology 2, 135-145.
Rug M and Ruppel A 2000. Toxic activities of the plant Jatropha curcas against intermediate snail hosts and larvae of schistosomes. Tropica Medicine and International Health 5, 423-430.

Sakagami H, Jiang Y, Kusama K, Atsumi T, Ueha T, Toguchi M, Iwakura I, Satoh K, Ito H, Hatano T and Yoshida T 2000. Cytotoxic activity of hydrolyzable tannins against human oral tumor cell lines - a possible mechanism. Phytomedicine 7, 39-47.

Sánchez NR, Spörndly E and Ledin I 2006. Effect of feeding different levels of foliage of Moringa oleifera to creole dairy cows on intake, digestibility, milk production and composition. Livestock Science 101, 24-31.

Schreurs NM, Tavendale MH, Lane GA, Barry TN and McNabb WC 2004. Effect of white colver (Trifolium repens), perennial grass (Lolium perenne) and Lotus corniculatus on in vitro skatole and indole formation. Proceedings of the 25th biennial conference of the Australian Society of Animal Production: animal production in Australia, 4-8 July 2004, Victoria, Australia, pp. 164-167.

Sen S, Makkar HPS, Muetzel S and Becker K 1998a. Effect of quillaja saponins and Yucca schidigera plant extract on growth of Escherichia coli. Letters in Applied Microbiology 27, 35-38.

Sen S, Makkar HPS and Becker K 1998b. Alfalfa saponins and their implication in animal nutrition. Journal of Agricultural and Food Chemistry 46, 131-140. Serrano JrA, Focken U, Francis G, Makkar HPS and Becker K 1998. Effects of quillaja saponins on the activity of selected gut and liver enzymes of carp, Cyprinus carpio. In Book of abstracts of the fifth Asian fisheries forum and international conference on fisheries and food security beyond the year 2000 (ed. P Jarayabhand, N Chaitanawisuti, A Sophon, A Kritsanapuntu and A Panichpol), p. 204. Aquatic Resources Research Institute, Chulalongkorn University, Bangkok, Thailand.

Shah MA and Mir PS 2004. Effect of dietary fenugreek seed on dairy cow performance and milk characteristics. Canadian Journal of Animal Science 84, 725-729.

Siddhuraju P and Becker K 2001a. Effect of various domestic processing methods on antinutrients and in vitro protein and starch digestibility of two indigenous varieties of Indian tribal pulse, Mucuna pruriens var. utilis. Journal of Agricultural and Food Chemistry 49, 3058-3067.

Siddhuraju P and Becker K 2001b. Preliminary nutritional evaluation of Mucuna seed meal (Mucuna pruriens var. utilis) in common carp (Cyprinus carpio L.): an assessment by growth performance and feed utilisation. Aquaculture 196, 105-123.

Siddhuraju P and Becker K 2001c. Species/variety differences in biochemical composition and nutritional value of Indian tribal legumes of the genus Canavalia. Nahrung/Food 45, 224-233.

Siddhuraju P and Becker K 2002. Effect of phenolic nonprotein amino acid L-dopa (L-3,4-dihydroxyphenylalanine) on growth performance, metabolic rates and feed nutrient utilization of common carp (Cyprinus carpio L.). Aquaculture Nutrition 8, 69-77.

Siddhuraju P and Becker K 2003. Antioxidant properties of various solvent extracts of total phenolic constituents from three different agroclimatic origins of drumstick tree (Moringa oleifera Lam.) leaves. Journal of Agricultural and Food Chemistry 51, 2144-2155.

Siddhuraju P and Becker K 2005. Nutritional and antinutritional composition, in vitro amino acid availability, starch digestibility and predicted glycemic index of differentially processed mucuna beans (Mucuna pruriens var. utilis): an under-utilised legume. Food Chemistry 91, 275-286.

Siddhuraju P, Becker K and Makkar HPS 2001. Chemical composition, protein fractionation, essential amino acid potential and antimetabolic constituents of an unconventional legume, Gila bean (Entada phaseoloides Merrill) seed kernel. Journal of the Science of Food and Agriculture 82, 192-202.

Siddhuraju P, Mohan PS and Becker K 2002. Studies on the antioxidant activity of Indian Laburnum (Cassia fistula L.): a preliminary assessment of crude extracts from stem bark, leaves, flowers and fruit pulp. Food Chemistry 79, 61-67.

Siddhuraju P, Makkar HPS and Becker K 2004. Essential amino acids and antimetabolites in the seed kernel of an unconventional legume, Gila bean (Entada phaseoloides Merrill). In Poisonous plants and related toxins (ed. T Acamovic, CS Stewart and TW Pennycott), pp. 377-386. CABI Publishing, Wallingford, UK.

Singh B, Bhat TK and Singh B 2003. Potential therapeutic applications of some antinutritional plant secondary metabolites. Journal of Agricultural and Food Chemistry 51, 5579-5597. 
Śliwiński BJ, Soliva CR, Machmüller A and Kreuzer M 2002a. Efficacy of plant extracts rich in secondary constituents to modify rumen fermentation. Animal Feed Science and Technology 101, 101-114.

Śliwiński BJ, Kreuzer M, Wettstein HR and Machmüller A 2002b. Rumen fermentation and nitrogen balance of lambs fed diets containing plant extracts rich in tannins and saponins and associated emissions of nitrogen and methane. Archiv für Tierernährung 56, 379-392.

Solsoloy AD and Solsoloy TS 1997. Pesticidal efficacy of formulated Jatropha curcas oil on pests of selected field crops. In Biofuels and industrial products from Jatropha curcas (ed. GM Gübitz, M Mittelbach and M Trabi), pp. 216-226. Dbv-Verlag für Technische Universität Graz, Graz, Austria.

Steinbronn S 2002. Impact of dietary quillaja saponins on growth, sex ratio and reproduction of Nile tilapia (Oreochromis niloticus L.) under field conditions in Bangladesh. Masters, University of Hohenheim, Stuttgart, Germany.

Suarez M, Entenza JM, Doerries C, Meyer E, Bourquin L, Sutherland J, Marison I, Moreillon P and Mermod N 2003. Expression of a plant-derived peptide harbouring water-cleaning and antimicrobial activities. Biotechnology and Bioengineering 81, 13-20.

Suarez M, Haenni M, Canarelli S, Fisch F, Chodanowski P, Servis C, Michielin O, Freitag R, Moreillon P and Mermod N 2005. Structure-function characterization and optimization of a plant-derived antibacterial peptide. Antimicrobial Agents and Chemotherapy 49, 3847-3857.

Suzuki K, Kawauchi H and Nagahama Y 1988a. Isolation and characterization of two distinct salmon gonadotropins from chum salmon pituitary glands. General and Comparative Endocrinology 71, 292-301.

Suzuki K, Kawauchi H and Nagahama Y 1988b. Isolation and characterization of subunits from two distinct salmon gonadotropins. General and Comparative Endocrinology 71, 302-306.

Tapondjou AL, Miyamoto T, Mirjolet JF, Guilbaud N and Lacaille-Dubois M-A 2005. Pursaethosides $A-E$, triterpene saponins from Entada pursaetha. Journal of Natural Products 68, 1185-1190.

Tavendale MH, Lane GA, Schreurs NM, Fraser K and Meagher LP 2005. The effects of condensed tannins from Dorycnium rectum on skatole and indole ruminal biogenesis for grazing sheep. Australian Journal of Agricultural Research 56, 1331-1337.

Taylor WG, Zulyniak HJ, Richards KW, Acharya SN, Bittman S and Elder JL 2002. Variation in diosgenin levels among 10 accessions of fenugreek seeds produced in western Canada. Journal of Agricultural and Food Chemistry 50 5994-5997.

Teferedegne B 2000. New perspectives on the use of tropical plants to improve ruminant nutrition. Proceedings of Nutrition Society 59, 209-214.

Teferedegne B, McIntosh F, Osuji PO, Odenyo A, Wallace RJ and Newbold CJ 1999. Influence of foliage from different accessions of the subtropical leguminous tree, Sesbania sesban, on ruminal protozoa in Ethiopian and Scottish sheep. Animal Feed Science and Technology 78, 11-20.

Thalib A, Widiawati Y, Hamid H, Suherman D and Sabrani M 1996. The effects of saponin from Sapindus rarak fruit on rumen microbes and performance of sheep. Jurnal Ilmu Ternak dan Veteriner 2, 17-20.

Tsao R, Reuber M, Johnson L and Coats JR 1996. Insecticidal toxicities of glucosinolate-containing extracts from cramble seeds. Journal of Agricultural Entomology 13, 109-120.

Tokura M, Ushida K, Miyazaki K and Kojima Y 1997. Methanogens associated with rumen ciliates. FEMS Microbiology Ecology 22, 137-143.

Tschöp M, Smiley DL and Heiman ML 2000. Ghrelin induces adiposity in rodents. Nature 407, 908-913.

Van den Berg AJJ, Horstein SFAJ, Ketternes-van den Bosch JJ, Kroes BH, Beukelman CJ, Leeflang BR and Labadie RP 1995. Curcacycline A - a novel cyclic octapeptide isolated from the latex of Jatropha curcas L. FEBS Letter 358 215-218.

Vasta $V$ and Priolo A 2006. Ruminant fat volatiles as affected by diet. A review. Meat Science 73, 218-228.

Vasta ML, Pennisi P, Bella M and Priolo A 2005. Effect of dietary condensed tannins on lamb intramuscular fatty acids. Proceedings of the XIth seminar of the Sub-Network FAO-CIHEAM on Sheep and Goat Nutrition, 8-10 September 2005, Catania, Italy, p. 23.

Waghorn GC, Shelton ID and McNabb WC 1994. Effects of condensed tannins in Lotus pedunculatus on its nutritive value for sheep. 1. Non-nitrogenous aspects. Journal of Agricultural Science, Cambridge 123, 99-107.

Wallace RJ, Arthaud L and Newbold CJ 1994. Influence of Yucca schidigera extract on ruminal ammonia concentrations and ruminal microorganism. Applied and Environmental Microbiology 60, 1762-1767.

Wallace RJ, McEwan NR, McIntosh FM, Teferedegne B and Newbold CJ 2002. Natural products as manipulators of rumen fermentation. Asian-Australasian Journal of Animal Science 15, 1458-1468.

Wang Y, Waghorn GC, Barry TN and Shelton ID 1994. The effect of condensed tannins in Lotus corniculatus on plasma metabolism of methionine, cystine and inorganic sulphate by sheep. British Journal of Nutrition 72, 923-935.

Wang Y, Douglas GB, Waghorn GC, Barry TN, Foote AG and Purchas RW 1996. Effect of condensed tannins upon the performance of lambs grazing Lotus corniculatus and lucerne (Medicago sativa). Journal of Agricultural Science, Cambridge 126, 87-98.

Wang Y, McAllister TA, Yanke LJ, Xu ZJ, Cheeke PR and Cheng KJ 2000a. In vitro effects of steroidal saponins from Yucca schidigera extract on rumen microbial protein synthesis and rumen fermentation. Journal of the Science of Food and Agriculture 80, 2114-2122.

Wang Y, McAllister TA, Yanke LJ, Xu ZJ and Cheeke PR 2000b. Effects of steroidal saponin from Yucca schidigera extract on ruminal microbes. Journal of Applied Microbiology 88, 887-896.

Wei T, Sun H, Zhao X, Hou J, Hou A, Zhao Q and Xin W 2002. Scavenging of reactive oxygen species and prevention of oxidative neuronal cell damage by a novel gallotannin, Pistafolia A. Life Sciences 70, 1889-1899.

Win B and Jongen F 1996. Glucosinolates in brassica: occurrence and significance as cancer-modulating agents. Proceedings of the Nutrition Society $55,433-446$.

Wina E 2005. The utilization of Sapindus rarak DC. Saponins to improve ruminant production through rumen manipulation. Masters, University of Hohenheim, Stuttgart, Germany.

Wina E, Muetzel S and Becker K 2005a. The impact of saponins or saponincontaining plant materials on ruminant production - a review. Journal of Agricultural and Food Chemistry 53, 8093-8105.

Wina E, Muetzel S, Hoffman E, Makkar HPS and Becker K 2005b. Effect of secondary compounds in forage on rumen microorganisms qualified by $16 \mathrm{~S}$ and $18 \mathrm{~S}$ rRNA. In Applications of gene-based technologies for improving animal production and health in developing countries (ed. HPS Makkar and GJ Viljoen), pp 397-410. Springer, Dordrecht, The Netherlands.

Wina E, Muetzel S, Hoffmann E, Makkar HPS and Becker K 2005c. Saponins containing methanol extract of Sapindus rarak affect microbial fermentation microbial activity and microbial community structure in vitro. Animal Feed Science and Technology 121, 159-174.

Yang LL, Lee CY and Yen KY 2000. Induction of apoptosis by hydrolysable tannins from Eugenia jambos L. on human leukemia cells. Cancer Letters 157, $65-67$.

Yang RY, Tsou SCS, Lee TC, Chang L-C, Kuo G and Lai P-Y 2006. Moringa, a novel plant rich in antioxidants, bioavailable iron, and nutrients. American Chemical Society Symposium Series 925, 224-239. 